\title{
PENGARUH PROGRAM CONSUMER PROMOTION NADA SAMBUNG PRIBADI (NSP) 1212 TELKOMSEL TERHADAP RESPON KONSUMEN DALAM PENGGUNAANNYA (Survei pada Mahasiswa FPIPS UPI Bandung)
}

\author{
Rd. Dian H. Utama \\ Rani Aprilliani
}

\begin{abstract}
Abstrak
Berbagai perusahaan provider penyedia layanan telekomunikasi, baik GSM maupun CDMA, menawarkan berbagai variasi fasilitas layanan atau content. Salah satu layanan yang paling diminati oleh konsumen diantaranya layanan ring tone atau ring back tone. Salah satu perusahaan yang melaksanakan bisnis ring back tone adalah Telkomsel dengan nama layanan NSP 1212. Strategi yang sedang diterapkannya yaitu program consumer promotion melalui undian, premium (diskon), pengujian gratis, deals, kontes dan hadiah (gift) pada NSP 1212. Hal ini dilakukan tak lain untuk meningkatkan respon konsumen dalam penggunaan layanan NSP 1212. Tujuan penelitian ini untuk mengetahui gambaran mengenai program consumer promotion NSP 1212 Telkomsel yang terdiri dari undian, premium (diskon), pengujian gratis, deals, kontes dan hadiah (gift). Respon konsumen NSP 1212 Telkomsel yang terdiri dari sadar, tertarik, evaluasi, mencoba dan adopsi. Serta untuk mengetahui seberapa besar pengaruh program consumer promotion NSP 1212 Telkomsel terhadap respon konsumen dalam penggunaannya pada mahasiswa FPIPS UPI Bandung.

Berdasarkan variabel yang diteliti maka jenis penelitian ini adalah penelitian deskriptif dan verifikatif. Jangka waktu penelitian bersifat cross sectional method. Populasi penelitian ini berjumlah 973 orang mahasiswi FPIPS UPI angkatan 2007 pengguna layanan NSP 1212. Berdasarkan teknik penarikan sampel secara simple random sampling dan dengan menggunakan rumus Harun Al Rasyid diperoleh sampel sebesar 99 sampel, namun untuk meningkatkan keakuratan maka jumlah sampel yang diteliti ditambah sehingga berjumlah 100 sampel. Data yang digunakan adalah data primer dan sekunder dengan teknik pengumpulan data melalui wawancara, observasi, penyebaran kuesioner dan studi literatur. Pengujian hipotesis dilakukan dengan menggunakan path analysis dengan bantuan software komputer SPSS.

Hasil penelitian menunjukkan consumer promotion NSP 1212 Telkomsel secara keseluruhan dinilai cukup dengan indikator undian ditinjau dari kemenarikan program undian merupakan dimensi yang paling tinggi mendapatkan skor, sedangkan perolehan hasil pada dimensi kontes mendapatkan skor yang paling rendah dari dimensi-dimensi lainnya. Respon konsumen yang terdiri dari sadar, tertarik, evaluasi, mencoba dan adopsi secara umum dinilai cukup dengan indikator sadar memperoleh skor yang paling tinggi, sedangkan indikator adopsi mendapatkan skor yang paling rendah. Terdapat pengaruh antara program consumer promotion terhadap respon konsumen dalam penggunaan nada sambung pribadi NSP 1212 Telkomsel, dengan kategori kuat.
\end{abstract}

Kata Kunci: Consumer Promotion dan Respon Konsumen

\section{PENDAHULUAN}

Perkembangan ilmu pengetahuan dan teknologi secara global dapat berdampak pada perkembangan perekonomian, yang akan semakin memperketat persaingan dalam dunia usaha terutama pada setiap sektor industri. Hal ini dapat menjadi pemicu bagi setiap sektor industri untuk dapat meningkatkan kinerja dan mengembangkan strateginya agar dapat mencapai tujuan usahanya. Saat ini Indonesia telah memasuki era globalisasi dimana telekomunikasi mempunyai peranan yang sangat penting bagi masyarakat. Industri telekomunikasi merupakan salah satu sektor industri dengan kondisi persaingan yang ketat.

Persaingan tersebut mulai tumbuh pada tahun 1995, ketika pemerintah telah memberlakukan liberalisasi pada komunikasi seluler. Sejak diberlakukannya liberalisasi tersebut, mulai bermunculan provider-provider penyedia layanan telekomunikasi seluler yang membawa perubahan

Pengaruh Program Consumer Promotion Nada Sambung Pribadi (NSP) 1212 Telkomsel terhadap Respon Konsumen dalam Penggunaannya 
besar dari monopoli market ke arah competitive market. Adapun pertumbuhan sektor-sektor industri dapat dilihat pada Tabel 1 di halaman berikutnya.

\section{Tabel 1}

Pertumbuhan Market Size Beberapa Sektor Industri 2004-2007

\begin{tabular}{|c|c|c|c|c|c|c|c|c|}
\hline \multirow{2}{*}{ Sektor } & \multicolumn{4}{|c|}{ Nominal } & \multicolumn{4}{|c|}{ Pertumbuhan (\%) } \\
\hline & 2004 & 2005 & 2006 & 2007 & 2004 & 2005 & 2006 & 2007 \\
\hline Penerbangan (Rp Miliar) & 9178,4 & 10362,3 & 11515,8 & 13744,8 & 28,2 & 10,4 & 11,1 & 19,4 \\
\hline Biro Perjalanan (Rp Miliar) & 15093,3 & 15902,9 & 17342,1 & 20016,1 & 9,5 & 5,6 & 9,1 & 15,4 \\
\hline Perhotelan (Rp Miliar) & 11840,5 & 12365,6 & 12694,4 & 13621,4 & 11,0 & 6,7 & 2,7 & 7,3 \\
\hline $\begin{array}{l}\text { Restoran dan Industri fast food } \\
\text { (Rp Miliar) }\end{array}$ & 37267,7 & 39648,1 & 42368,9 & 44640,1 & 6,0 & 6,4 & 6,9 & 5,4 \\
\hline $\begin{array}{l}\text { Departemen Stores (Rp Miliar) } \\
\text { (sales) }\end{array}$ & 9419,6 & 11216,4 & 13408,9 & 16062,8 & 9,3 & 19,1 & 19,5 & 19,8 \\
\hline Asuransi (Rp Miliar) (sales) & 2474,8 & 3408,9 & 5052,4 & 7619,7 & 50,9 & 42,6 & 48,2 & 50,8 \\
\hline Supermarket (Rp Miliar) (sales) & 3695,0 & 4260,1 & 5079,2 & 6104,9 & 26,9 & 12,4 & 19,2 & 20,2 \\
\hline \multicolumn{9}{|l|}{ Otomotif } \\
\hline - Penjualan Mobil (ribu unit) & 483 & 533,9 & 309,7 & 415,6 & 36,4 & 10,5 & $-42,0$ & 34,2 \\
\hline - Penjualan Motor (juta unit) & 3,9 & 5,1 & 4,1 & 5,0 & 38,3 & 30,5 & $-18,6$ & 20,8 \\
\hline Perbankan (Rp Miliar) & 438,88 & 689,7 & 831,4 & 1208,0 & 28,3 & 24,6 & 20,6 & 23,6 \\
\hline $\begin{array}{l}\text { Tekstil dan Garmen (Rp Miliar) } \\
\text { (sales) }\end{array}$ & 3914,6 & 4246,4 & 4009,5 & 4204,8 & 14,4 & 8,5 & $-5,6$ & 4,9 \\
\hline Farmasi (Rp Triliun) (sales) & 2798,4 & 3038,4 & 3283,0 & 3661,9 & 11,3 & 8,6 & 8,1 & 11,5 \\
\hline Toiletris (Rp Miliar) (sales)h & 9228,7 & 10200,2 & 11568,1 & 13203,3 & 10,5 & 10,5 & 13,4 & 14,1 \\
\hline Rokok (Miliar Batang) & 214,0 & 225,5 & 240,8 & 255,6 & 10,6 & 5,4 & 6,8 & 6,2 \\
\hline $\begin{array}{l}\text { Makanan dan Minuman (Rp } \\
\text { Miliar) }\end{array}$ & 118,461 & 121377,9 & 123066,1 & 124663,8 & 1,7 & 2,7 & 1,4 & 1,3 \\
\hline $\begin{array}{l}\text { Properti dan Real Estate (Rp } \\
\text { Miliar) (sales) }\end{array}$ & 7696,3 & 9769,9 & 11751,9 & 14245,2 & 13,4 & 26,9 & 20,3 & 21,2 \\
\hline \multicolumn{9}{|l|}{ Telekomunikasi } \\
\hline - Selular (juta pelanggan) & 29,8 & 45,7 & 59,0 & 75,8 & 21,1 & 53,1 & 29,2 & 28,4 \\
\hline - Sambungan telp (juta) & 8,4 & 12,7 & 14,4 & 15,9 & 3,3 & 27,6 & 12,8 & 10,7 \\
\hline
\end{tabular}

Sumber: Danareksa Research Institute 2006 dan 2007

Berdasarkan data pertumbuhan industri telekomunikasi dari Danareksa Research Institute, jumlah pelanggan telekomunikasi mengalami kenaikan yang cukup signifikan dari tahun ke tahun. Pelanggan seluler pada tahun 2004 sebesar (29,8 juta pelanggan), pada tahun 2005 sebesar (45,7 juta pelanggan ), pada tahun 2006 (59,0 juta pelanggan) dan pada tahun 2007 sebesar $(75,8$ juta pelanggan ), dengan pertumbuhan sebesar $(21,1 \%)$ pada tahun $2004,(53,1 \%)$ tahun 2005 , $(29,2 \%)$ tahun 2006 dan $(28,4 \%)$ pada tahun 2007. Sementara pelanggan sambungan telepon pada tahun 2004 sebesar (8,1 juta pelanggan), pada tahun 2005 sebesar (12,7 juta pelanggan), pada tahun 2006 sebesar ( 1,4 juta pelanggan) dan pada tahun 2007 sebesar (15,9 juta pelanggan), dengan pertumbuhan sebesar $(3,3 \%)$ tahun $2004,(27,6 \%)$ tahun 2005, (12,8\%) tahun 2006 dan (10,7\%) pada tahun 2007.

Hal ini menunjukan bahwa industri ini mengalami perkembangan yang pesat dan perlu dipertahankan, tentunya ini akan menjadi tantangan bagi perusahaan untuk tetap dapat bertahan dalam persaingan industri ini. Persaingan tersebut mendorong para industri telekomunikasi untuk mengembangkan dan melakukan inovasi terhadap produk-produknya.

Perkembangan dunia telepon seluler (ponsel) sebagai bagian dari teknologi telekomunikasi berjalan begitu cepat. Keinginan masyarakat untuk selalu mengikuti perkembangan jaman sekarang semakin besar. Pada awal munculnya teknologi seluler di negara ASEAN yang telah maju (Brunei, Malaysia dan Singapura), pemakaian telepon seluler hanya sebagai pelengkap terhadap telepon konvensional. Sementara di beberapa negara berkembang (Kamboja, Filipina dan Indonesia) telepon seluler merupakan pengganti telepon konvensional.

Di Indonesia teknologi yang dikenal lama oleh masyarakat dalam telekomunikasi adalah teknologi GSM dan CDMA yang baru muncul beberapa tahun ke belakang. Saat ini semakin banyak bermunculan provider penyelenggara jasa telepon, berdasarkan Asosiasi Telepon Seluler Indonesia (ATSI) terdapat sebelas perusahaan yang mendapatkan izin sebagai provider seluler di 
Indonesia, tetapi yang beroperasi sebanyak sembilan perusahaan. Berdasarkan jumlah tersebut, enam diantaranya pemain lama dan tiga perusahaan pemain baru. Namun dari jumlah tersebut, yang menggunakan teknologi GSM dan yang menggunakan teknologi CDMA masingmasing 4 perusahaan, yang menggunakan sistem AMPS/NMT ada 2 perusahaan, dan 1 perusahaan yang menggunakan teknologi NMT 450.

Saat ini masyarakat pengguna jasa telekomunikasi seluler di Indonesia kurang lebih berjumlah tujuh puluh lima juta pelanggan. Dimana persaingan produk baik teknologi GSM dan CDMA berjalan semakin ketat. Provider seluler harus berpacu dalam memberikan layanan terbaik, meski pada akhirnya pelanggan dan calon pelanggan juga lah yang memutuskan produk apa yang mereka pilih. Sebab masyarakat semakin rasional dan terus menginginkan layanan lebih.

Teknologi GSM hingga kini masih tetap diadopsi oleh empat perusahaan provider seluler seperti PT. Telkomsel, PT. Excelecomindo, PT. Natrindo Seluler/Lippo Telecom dan PT. Indosat Tbk. Namun pada awal tahun 2007 muncul sebuah perusahaan baru yang juga menggunakan teknologi GSM yaitu Hutchinson Indonesia. Sementara CDMA juga sudah banyak perusahaan yang bermain di dalamnya, diantaranya PT. Telkomsel, PT. Bakrie Telecom dan Mobile8.

Di Indonesia pengguna telepon seluler saat ini masih didominasi layanan suara dan layanan pesan singkat (SMS) yang jumlahnya bisa mencapai 99\%. Kontribusi kedua layanan itu terhadap pendapatan para provider seluler cukup tinggi, yaitu antara $75 \%-85 \%$ dari suara sementara, SMS antara 10-25\%, selebihnya 5\% dari layanan data. (www.wordpress.com).

Gaya hidup masyarakat di Indonesia cenderung lebih akomodatif terhadap setiap fitur baru layanan telekomunikasi. Provider seluler menawarkan banyak fitur-fitur atau fasilitas yang dapat dinikmati oleh pelanggannya. Salah satu fitur yang ditawarkan provider adalah layanan Ring Tone dan Ring Back Tone (RBT) atau nada tunggu, layanan ini sudah diperkenalkan providerprovider seluler dari tahun 2004 silam. Fitur ini berupa lagu-lagu yang sedang hits ataupun tembang-tembang lawas baik lokal maupun interlokal, yang dapat dinikmati apabila pelanggan mengaktifkan RBTnya, sehingga penelefon yang akan menghubungi pelanggan akan terhibur untuk mendengarkan lagu yang telah di set pelanggan sebelum pelanggan mengangkat teleponnya. Tingginya minat pelanggan seluler menggunakan fasilitas RBT menjadi berkah pula bagi provider telekomunikasi.

PT. Telkomsel sebagai provider telekomunikasi berbasis seluler pertama dan terbesar merupakan pelopor peluncuran Ring Back Tone di Indonesia yaitu pada tanggal 1 Sepetember 2004, dengan nama layanan Nada Sambung Pribadi (NSP) 1212, peluncuran layanan tersebut merupakan salah satu wujud kepedulian Telkomsel dalam rangka meningkatkan teledensia di Indonesia dengan memberikan kesempatan bagi masyarakat luas untuk dapat menikmati layanan telekomunikasi.

Fitur RBT menyumbang 2\% terhadap total pendapatan Telkomsel. Total pelanggan aktif RBT Telkomsel rata-rata 6,7 juta atau sekitar 11,5\% dari total pelanggan Telkomsel yang mencapai 58 juta. Setiap hari traffic RBT rata-rata mencapai 100.000, dan pada waktu-waktu tertentu seperti Bulan Ramadhan trafficnya meningkat menjadi 120.000/hari. Berdasarkan angka tersebut bisa diperkirakan, revenue yang diperoleh Telkomsel dari RBT mencapai Rp. 900.000.000/hari. Revenue yang didapat dari RBT akan dibagi dengan Content provider. (SWA 03/XXIII/1-14 Februari 2007).

Keuntungan dari bisnis RBT dibagi secara proporsional dengan pihak-pihak yang terlibat, seperti provider, perusahaan rekaman dan artis. Kerja sama ke tiga pihak ini didasari kepercayaan (trust) yang tinggi. Kerja sama ke tiga pihak inipun sampai ke pemasaran tetapi sifatnya hanya proyek, seperti provider mensponsori kegiatankegiatan tertentu.

Sumbangan dari layanan RBT ini cukup signifikan, sehingga provider-provider telekomunikasi yang menyediakan layanan RBT melakukan berbagai cara agar pelanggannya mengaktifkan RBT. Tantangan yang paling berat bagi provider justru dalam mengedukasi pelanggannya untuk menggunakan RBT, pasalnya karakter pengguna seluler di Indonesia masih didominasi oleh pengguna layanan SMS dan suara.

Di sinilah diperlukan sosialisasi dan edukasi dari provider Telkomsel untuk meyakinkan pengguna seluler bahwa layanan bernilai tambah seperti Ring Back Tone ini adalah sesuatu yang pantas dan perlu dinikmati. Adapun data providerprovider bisnis Ringtone/Ring Back Tone dapat dilihat pada Tabel 2 di halaman berikutnya. 
Tabel 2

Provider Bisnis Ring Tone dan Ring Back Tone

\begin{tabular}{|l|l|l|l|r|r|}
\hline $\begin{array}{c}\text { Nama } \\
\text { Provider }\end{array}$ & \multicolumn{1}{|c|}{$\begin{array}{c}\text { Nama } \\
\text { Layanan }\end{array}$} & \multicolumn{1}{|c|}{ Cakupan Area } & Launching & $\begin{array}{c}\text { Jumlah } \\
\text { Pelanggan }\end{array}$ & $\begin{array}{c}\text { Total } \\
\text { Pelanggan }\end{array}$ \\
\hline Telkomsel & NSP 1212 & Seluruh Indonesia & $\mathbf{0 1 - 0 9 - 2 0 0 4}$ & $\mathbf{6 . 7 0 0 . 0 0 0}$ & $\mathbf{5 8 . 0 0 0 . 0 0 0}$ \\
\hline XL & $\begin{array}{l}\text { Nada } \\
\text { Tungguku }\end{array}$ & $\begin{array}{l}\text { Jawa, Bali, Sumatera, } \\
\text { dan Kalimantan }\end{array}$ & $01-06-2005$ & 425.000 & 7.000 .000 \\
\hline Flexi & Flexi Tone & Jabotabek dan Bandung & $28-07-2005$ (uji coba Mei 2005) & 76.283 & 4.100 .000 \\
\hline Mobile8 & Ring Go & Jawa dan Madura & $01-07-2005$ (uji coba Mei 2005) & 195.000 & 1.300 .000 \\
\hline Indosat & I Ring & Jawa dan Sumatera & 07-12-2004 (uji coba Agustus 2004) & 54.000 & 14.400 .000 \\
\hline
\end{tabular}

Sumber Sumber: SWA 03/XXIII/1-14 Februari 2008

Berdasarkan data di atas dapat dilihat bahwa Telkomsel dibandingkan dengan provider lainnya merupakan provider yang memiliki pelanggan Ring Back Tone (RBT) terbanyak yaitu sebesar 6,7 juta dari 58 juta pelanggan yang dimilikinya. Sementara provider lainnya seperti XL memiliki jumlah pelanggan 425.000 dari 7 juta pelanggan, disusul dengan Flexi, Mobile8 dan Indosat dengan jumlah pelanggan RBT masing-masing sebesar 76.283, 195.000 dan 54.000 dengan total pelanggan masingmasing sebesar 4,1 juta, 1,3 juta dan 14,4 juta.

NSP 1212 Telkomsel telah berjalan sekitar 4 tahun lebih, tetapi jumlah pelanggan yang menggunakan layanan ini hanya sebesar 6,7 juta atau sekitar $11,55 \%$ saja dari jumlah total sebesar 58 juta pelanggan. Hal ini membuktikan respon konsumen terhadap layanan ini tidak memenuhi target Telkomsel yaitu sekitar 15 juta pelanggan atau sekitar 25\% dari total keseluruhan pelanggan Telkomsel sampai akhir tahun 2008. Pertengahan tahun 2007 sampai dengan pertengahan tahun 2008 jumlah pelanggan Telkomsel yang menggunakan layanan NSP 1212 ini tidak mencapai target yang sudah ditentukan oleh perusahaan untuk tiap bulannya. Seperti terlihat dalam Tabel 3.
Berdasarkan Tabel 3, jumlah pelanggan yang menggunakan layanan NSP 1212 untuk tahun 2007 selalu di bawah target pelanggan yang telah ditetapkan oleh Telkomsel, dengan rata-rata 4,38 juta pelanggan atau $9 \%$ dari jumlah total pelanggan sebesar 50 juta orang. Tahun 2008 Telkomsel menambah jumlah targetnya menjadi 15 juta, dikarenakan jumlah total pelanggan Telkomsel yang bertambah menjadi 58 juta orang, jumlah pengguna NSP 1212 ini selalu di bawah target yang telah ditetapkan oleh Telkomsel yakni dengan rata-rata 6,71 juta pelanggan atau $11,5 \%$. Hal tersebut belum memenuhi harapan Telkomsel yang menentukan target sebesar 15 juta atau $25 \%$ dari total keseluruhan pelanggan sebanyak 58 juta orang.

Produk-produk kartu Telkomsel berupa GSM terdiri dari tiga yaitu kartu Simpati, kartu As dan kartu Halo. Jumlah pengguna layanan NSP 1212 terbanyak adalah pengguna kartu prabayar Simpati yaitu sebesar $55 \%$, sementara pelanggan kartu prabayar As yang menggunakan layanan NSP ini sebanyak $33 \%$ dan pelanggan paska bayar Kartu halo yang menggunakan layanan ini hanya sebesar $12 \%$, hal ini menunjukkan respon pelanggan kartu Simpati lebih besar dari respon pelanggan kartu AS dan kartu

TABEL 3

Target Pelanggan dan Jumlah Pelanggan yang Menggunakan NSP 1212 Periode Juli Tahun 2007- Juni Tahun 2008

\begin{tabular}{|l|c|c|c|c|c|}
\hline \multicolumn{2}{|c|}{ Tahun 2007 } & \multicolumn{3}{c|}{ Tahun 2008 } \\
\hline Bulan & $\begin{array}{c}\text { Target } \\
\text { Pelanggan }\end{array}$ & $\begin{array}{c}\text { Jumlah Pelanggan } \\
\text { yang Menggunakan }\end{array}$ & Bulan & $\begin{array}{c}\text { Target } \\
\text { Pelanggan }\end{array}$ & $\begin{array}{c}\text { Jumlah Pelanggan } \\
\text { yang Menggunakan }\end{array}$ \\
\hline Juli & 8 juta & 3,9 juta & Januari & 15 juta & 5,7 juta \\
\hline Agustus & 8 juta & 3,8 juta & Februari & 15 juta & 7,6 juta \\
\hline September & 8 juta & 5,6 juta & Maret & 15 juta & 6,8 juta \\
\hline Oktober & 8 juta & 4,9 juta & April & 15 juta & 5,9 juta \\
\hline November & 8 juta & 4,0 juta & Mei & 15 juta & 6,5 juta \\
\hline Desember & 8 juta & 4,1 juta & Juni & 15 juta & 7,8 juta \\
\hline \multicolumn{2}{|c|}{ Rata-rata } & 4,38 juta & \multicolumn{2}{c|}{ Rata-rata } & $\mathbf{6 , 7 1}$ juta \\
\hline
\end{tabular}

Sumber: www.swa.co.id 
Halo. Pengguna NSP mayoritas pelanggan kartu Simpati tetapi dalam hal ini Telkomsel berusaha meningkatkan respon keseluruhan pelanggan pengguna produk Telkomsel untuk mengaktifkan layanan NSP 1212. Bisa diprediksikan, segmen pelanggan NSP 1212 Telkomsel mayoritas dari kalangan remaja dan komunitas yang menggemari musik, asumsinya, perilaku segmen tersebut lebih mudah menyesuaikan dan memiliki gaya hidup yang dinamis. ( SWA 03/XXIII/1-14 Februari 2007).

Sebelumnya penulis melakukan pra penelitian pada mahasiswa FPIPS UPI dengan total responden 100 orang dengan menggunakan metode kuesioner yang di sebarkan secara random. Tabel 1.5 menunjukkan tanggapan tentang terakhir kali konsumen menggunakan NSP 1212 Telkomsel. Adapun data pra penelitian dapat dilihat pada Tabel 4 di bawah ini:

Tabel 4

Tanggapan tentang Terakhir Kali

Konsumen Menggunakan NSP 1212

\begin{tabular}{|c|c|}
\hline Tingkat Penggunaan & Persentase \\
\hline $1-2$ bulan & 10 \\
\hline $3-4$ bulan & 25 \\
\hline $5-6$ bulan & 15 \\
\hline $7-8$ bulan & 20 \\
\hline$>1$ tahun & 30 \\
\hline
\end{tabular}

Sumber : Survei Pra Penelitian

Berdasarkan data di atas dapat kita lihat bahwa jumlah konsumen yang menggunakan NSP 1212 1-2 bulan terakhir sebesar 10\%, 3-4 bulan terkhir sebesar 25\%, 5-6 bulan terakhir sebesar 15\%, 7-8 bulan terakhir sebesar $20 \%$ dan lebih dari 1 tahun terakhir sebesar 30\%. Hal ini mengindikasikan bahwa respon penggunaan NSP 1212 dari bulan ke bulan rata-rata mengalami penurunan. Hal tersebut dikarenakan kurang menariknya program layanan NSP 1212 yang monoton dari bulan ke bulannya. Penurunan tersebut yang selalu menyebabkan tidak terpenuhinya jumlah target konsumen pengguna NSP 1212 Telkomsel.

Keadaan tersebut tentunya menjadi bahan evaluasi Telkomsel untuk lebih meningkatkan minat para konsumennya untuk menggunakan layanan NSP 1212 salah satu cara yang dapat meningkatkan respon konsumen dengan cepat yaitu melalui program-program promosi yang bertujuan langsung kepada konsumen akhir, sehingga konsumen tertarik menggunakan fitur layanan NSP 1212 yang telah disediakan oleh Telkomsel.

Promosi penjualan (sales promotion) merupakan segala bentuk penawaran atau insentif jangka pendek yang ditujukan bagi pembeli, pengecer atau pedagang grosir dan dirancang untuk memperoleh respons spesifik dan segera. Secara garis besar terdapat tiga klasifikasi utama dari promosi penjualan yaitu, promosi konsumen (consumer promotion), promosi dagang (trade promotion) dan promosi wiraniaga (salesforce promotion). Berdasarkan demikian sales promotion yang tepat untuk digunakan dalam meningkatkan respon konsumen adalah consumer promotion, karena sales promotion ini lebih difokuskan pada konsumen sebagai sasaran akhir.

Sementara itu, sarana promosi yang digunakan adalah pemberian sampel, kupon berhadiah (melalui tutup botol, cangkang, logo, kemasan yang beralamat, dan sebagainya), pemberian hadiah secara langsung atau sayembara hadiah, hadiah demonstrasi, premium (diskon), kontes, pertunjukan bermacam-macam kesenian dengan tujuan promosi. Sales promotion dalam bentuk ini pada intinya ingin memanjakan konsumen, selain memenuhi keinginan produsen agar konsumen selalu membeli produk yang dipromosikan.

Menurut Stewart H. Rewoldt, James D. Scott dan Martin R. Marshaw (2005:174), promosi kepada konsumen mempunyai tujuan merangsang tanggapan pembeli secara cepat (quick buying response). Selain itu, promosi ini juga bertujuan untuk melakukan edukasi terhadap pelanggan atas produk yang memiliki kualitas baik.

Cara yang dilakukan oleh Telkomsel agar semua pengguna produk Telkomsel merespon baik terhadap layanan NSP 1212 Telkomsel dengan program promosi melalui program consumer promotion. Program promosi penjualan baru dapat dirancang dengan baik apabila tujuannya telah ditetapkan secara jelas. Tujuan promosi penjualan harus konsisten dengan strategi pemasaran, dan dirumuskan berdasarkan siapa targetnya, seperti pembeli akhir maka sangat penting dilakukan analisis lebih lanjut pada consumer promotion dalam mengevaluasi program-programnya yang telah dilakukan oleh perusahaan, kemudian diharapkan akan diketahui respon konsumen yang merupakan pelanggan Telkomsel terhadap penggunaan layanan NSP 1212 Telkomsel.

Berdasarkan latar belakang tersebut, maka dirumuskan masalah penelitian sebagai berikut:

1. Bagaimanakah gambaran mengenai program consumer promotion NSP 1212 Telkomsel yang terdiri dari undian, premium (diskon), pengujian 
gratis, deals, kontes dan hadiah (gift) pada mahasiswa FPIPS UPI Bandung

2. Bagaimanakah gambaran mengenai respon konsumen NSP 1212 Telkomsel yang terdiri dari sadar, tertarik, evaluasi, mencoba dan adopsi pada mahasiswa FPIPS UPI Bandung

3. Seberapa besar pengaruh program consumer promotion NSP 1212 Telkomsel terhadap respon konsumen dalam penggunaannya pada mahasiswa FPIPS UPI Bandung

\section{KERANGKA PEMIKIRAN}

Freddy Rangkuti (2002:48) mendefenisikan pemasaran dalam persfektif yang luas. la mendefenisikan pemasaran sebagai proses kegiatan yang dipengaruhi oleh berbagai faktor sosial, budaya, politik, ekonomi, dan manajerial. Akibat dari pengaruh berbagai faktor tersebut adalah masing-masing individu ataupun kelompok mendapatkan kebutuhan dan keinginan dengan menciptakan, menawarkan dan menukarkan produk yang memiliki nilai komoditas.

Definisi pemasaran secara spesifik diartikan bahwa pemasaran tidak hanya sekedar memindahkan produk dari tangan produsen kepada konsumen, tetapi di dalamnya terdapat kegiatankegiatan lain yang diusahakan agar konsumen merasakan kepuasan, melakukan pembelian ulang, bahkan loyal terhadap produk tersebut.

Bauran pemasaran jasa merupakan alat yang perlu dipertimbangkan agar implementasi strategi pemasaran yang ditetapkan dapat berjalan sukses dan untuk membentuk karakteristik jasa yang ditawarkan kepada pelanggan. Bauran pemasaran jasa mencakup product, price, place, promotion, people, process, physical evidence dan customer service. Fandy Tjiptono (2006:31), Rambat Lupiyoadi dan A. Hamdani (2006:70).

Fandy Tjiptono (2006:31), Rambat Lupiyoadi dan A. Hamdani (2006:70) mendefinisikan setiap unsur bauran pemasaran jasa adalah sebagai berikut:

1. Product merupakan bentuk penawaran organisasi jasa yang ditujukan untuk mencapai tujuan organisasi melalui pemuasan kebutuhan dan keinginan pelanggan.

2. Pricing, keputusan bauran harga berkenaan dengan kebijakan strategis dan taktis, seperti tingkat harga, struktur diskon, syarat pembayaran, dan tingkat diskriminasi harga di antara berbagai kelompok pelanggan.
3. Promotion, bauran promosi tradisional meliputi berbagai metode untuk mengkomunikasikan manfaat jasa kepada pelanggan potensial dan aktual.

4. Place, keputusan distribusi menyangkut kemudahan akses terhadap jasa bagi para pelanggan potensial.

5. People, adalah semua pelaku yang memainkan sebagian penyajian jasa dan karenanya mempengaruhi persepsi pembeli.

6. Phisical Evidence, adalah petunjuk visual atau berwujud lainnya yang memberi bukti atas kualitas jasa.

7. Process adalah metode pengoperasian atau serangkaian tindakan yang umumnya berupa langkah-langkah yang diperlukan dalam suatu urutan yang telah ditetapkan.

8. Customer Service, makna layanan pelanggan berbeda antar organisasi. Layanan pelanggan dapat diartikan sebagai kualitas total jasa yang dipersepsikan oleh pelanggan.

Promosi merupakan salah satu faktor penentu keberhasilan salah satu program pemasaran. Betapa berkualitasnya suatu produk, bila konsumen belum pernah mendengarnya dan tidak yakin bahwa produk itu akan berguna baginya. Pada hakikatnya menurut Buchari Alma (Ratih Hurriyati, 2005:58), Promosi adalah suatu komunikasi pemasaran yang merupakan suatu aktivitas pemasaran yang berusaha menyebarkan informasi, mempengharuhi/membujuk, dan atau mengingatkan pasar sasaran atau perusahaan dan produknya agar bersedia menerima, membeli, dan loyal pada produk yang ditawarkan perusahaan.

Berdasarkan uraian di atas dapat disimpulkan tujuan utama dari promosi adalah menginformasikan, membujuk dan mengingatkan pelanggan tentang sasaran tentang perusahaan dan bauran pemasarannya.

Promosi adalah suatu cara untuk mempengaruhi perilaku serta mengubah setiap bagian dari bauran pemasaran. Promotional mix di dalamnya dikenal ada empat unsur yang saling mempengaruhi yaitu advertising (pengiklanan), personal selling (penjualan yang dilakukan dengan tatap muka), sales promotion (promosi penjualan), public relation (hubungan masyarakat). Sedangkan menurut Fandy Tjiptono dalam bukunya pemasaran strategic (2007: 223) mengemukakan lima unsur dari bauran promosi , yaitu:

1. Personal selling 
2. Mass Selling

3. Sales promotion (Promosi penjualan)

4. Public Relation (Hubungan Masyarakat)

5. Direct marketing

Sales Pomotion adalah bentuk persuasi langsung melalui penggunaan berbagai insetif yang dapat diatur untuk merangsang pembelian produk dengan segera dan/atau meningkatkan jumlah barang yang dibeli pelanggan. Melalui promosi penjualan perusahaan dapat menarik pelanggan baru, mempengaruhi pelanggannya untuk mencoba produk baru, mendorong pelanggan membeli lebih banyak, menyerang aktivitas promosi pesaing, meningkatkan impulse buying (pembelian tanpa rencana sebelumnya) taua mengupayakan kerjasama yang lebih

erat dengan pengecer. Secara umum tujuan dari sales promotion dapat digeneralisasikan menjadi/:

1. meningkatkan permintaan dari para pemakai industrial dan/atau konsumen akhir

2. meningkatkan kinerja pemasaran perantara

3. mendukung dan mengokdinasikan kegiatan personal selling dan iklan.

Sales Promotion dapat dikelompokan berdasarkan tujuan yang ingin dicapai. Pengelompokan tersebut adalah sebagai berikut:

1. Consumer promotion, yaitu promosi penjualan yang bertujuan untuk merangsang / mendorong pelanggan untuk membeli

2. Trade promotion, yaitu promosi penjualan yang bertujuan untuk mendorong/ merangsang padagang grosir, pengecer, eksportir, dan importir untuk memperdagangkan barang/jasa dari sponsor

3. Sales-force promotion, yaitu promosi penjualan yang bertujuan untuk memotivasi armada penjual.

Menurut Frans M. Royan (Cluster strategy, 2004:56) Consumer promotion merupakan promosi yang lebih difokuskan pada konsumen sebagai sasaran akhir. Consumer promotion memiliki berbagai bentuk program sesuai dengan tujuan promosi penjualannya, dan bentuk-bentuk program yang bertujuan untuk meningkatkan respon konsumen diantaranya adalah sebagai berikut:

1. Kupon

Kupon telah ada selama beberapa tahun dalam bentuk kartu yang biasanya dikumpulkan apabila konsumen membeli suatu produk tertentu, cara mainnya biasanya konsumen mengumpulkan sejumlah kupon untuk ditukarkan dengan hadiah yang telah disediakan oleh produsen.
2. Deals

Deals merupakan bentuk kesepakatan antara produsen dengan konsumen, biasanya produsen menawarkan produk baru yang diuji-cobakan pada konsumen secara gratis dalam beberapa waktu, apabila konsumen merasa puas atau menyukai produk yang ditawarkan maka dapat melakukan pembelian.

3. Premium (Diskon)

Dalam Fandy Tjiptono (2002:230), Berkowitz, E.N., et. Al. menyatakan bahwa "Diskon atau pengurangan harga bertujuan membentuk goodwill dengan konsumen". Goodwill tersebut bisa terbentuk karena konsumen lebih menyukai premium/pengurangan harga dan pada umumnya konsumen membeli karena pengurangan harga bukan karena barang.

Promosi pengurangan harga merupakan bentuk premium yang memberikan pengurangan harga berkisar antara 10\% hingga 25\% harga merek yang biasa (Terence A. Shimp, 2003:189)

Selain memberikan definisi Shimp (2003:225), mengemukakan pendapatnya bahwa promosi premium akan lebih efektif apabila tujuan pemasaran adalah sebagai berikut:

a. Memberikan imbalan kepada para pemakai merek yang sekarang

b. Membuat konsumen membeli kuantitas merek yang lebih besar daripada yang mereka lakukan, sehingga dapat memenangkan persaingan secara efektif.

c. Membentuk pola pembelian ulang setelah percobaan awal.

d. Menjamin bahwa dana promosi dapat menjangkau konsumen

Pengurangan harga menunjukkan keberhasilan promosi untuk dua alasan. Pertama, pengurangan harga mempunyai pertimbangan dapat menghemat uang konsumen. Kedua keuntungan yang segera. Tidak seperti rabat, penawaran uang kembali, kontes, undian dan promosi insentif lainnya, konsumen tidak perlu menunggu keuntungan yang segera.

\section{Kontes}

Kontes menawarkan hadiah kalau orang berhasil menyelesaikan tingkat keterampilan atau penilaian mental atau fisik yang lumayan sulit.

\section{Undian Berhadiah (Sweeptakes)}

Dalam undian gratis (free draw), pemenang ditentukan seluruhnya oleh peluang dan tidak dibolehkan meminta bayaran atau bukti pembelian apapun dari peserta. Undian gratis berbeda dari 
promosi kemenangan langsung dalam arti bahwa orang tidak tahu langsung apakah mereka menang atau tidak. Tahap kedua dalam undian gratis berbeda, orang diminta menunggu hingga tanggal penutupan untuk menyaksikan apakah dia terpilih menjadi pemenang.

Ada empat alasan penggunaan undian gratis:

a. Undian ini dapat sangat efektif dalam menimbulkan minat, kesadaran dan partisipasi. Undian gratis khususnya adalah penambah jumlah peminat (traffic-builder) yang kuat. Tidak adanya babak penentuan berarti bahwa undian gratis menarik hingga dua puluh kali lipat jumlah peserta dibanding kompetisi.

b. Undian ini mudah diselenggarakan oleh pelaku promosi, mudah diikuti konsumen, membutuhkan dana hadiah yang sudah ditetapkan, dan merupakan cara yang cepat dan mudah mengembangkan basis data pelanggan dan calon pelanggan.

c. Undian ini dapat melibatkan dorongan tersirat untuk membeli. Ini perlu dilakukan dengan hatihati.

d. Undian ini memungkinkan kesempatan yang sangat besar untuk melakukan kreativitas. Dibandingkan dengan kompetisi, sebagai alternatif utama bagi orang yang mencari cara dengan biaya tetap, undian gratis membutuhkan jauh lebih sedikit aturan, tidak memerlukan pertanyaan atau ujian, tetapi benar-benar memberikan kemungkinan penuh untuk segala jenis game.

6. Pengujian gratis (sampel)

Mengajak calon pembeli menguji-coba produk tanpa biaya dengan harapan mereka akan membeli. Biasanya konsumen terdoromg untuk mencoba produk baru, pengujian gratis atau sampel ini keunggulannya berisiko kecil bagi konsumen yang mencoba produk baru dengan kelemahan biaya yang tinggi bagi perusahaan.

7. Trading Stamps

Tradding Stamps adalah cap dagang yang diberikan pada bon penjualan. Cap-cap tersebut disimpan oleh para langganan dan bila mereka telah berhasil mengumpulkan suatu jumlah tertentu, mereka mendapat premium dan mungkin juga diberikan dalam bentuk uang atau barang. Tradding stamps adalah cara yang sangat efektif untuk menarik langganan.

8. Point-of-Purchase Displays
Pemajangan atau penempatan produk semenarik mungkin sehingga menimbulkan keinginan membeli sesuatu, yang tidak didorong oleh seseorang, tapi didorong oleh daya tarik, atau oleh penglihatan ataupun oleh perasaan lainnya.

9. Hadiah (Gift)

Produsen memberikan hadiah secara langsung kepada konsumen yang melakukan pembelian berulang-ulang terhadap suatu produk yang bertujuan untuk mempertahankan kesetiaan konsumen untuk tetap menggunakan produk yang ditawarkan.

Tidak semua program consumer promotion yang disebutkan di atas dapat dimplementasikan pada program layanan NSP 1212 Telkomsel, yaitu kupon, trading stamps dan point-of-purchase displays mengingat NSP 1212 merupakan fasilitas yang dapat dinikmati apabila kita melakukan transaksi pembelian dengan operator secara jarak jauh dengan memilih satu buah lagu berupa ring back tone pada hand phone yang tidak memiliki wujud benda (intangible).

Keterkaitan antara consumer promotion dengan respon konsumen bahwa dengan program-program promosi penjualan terutama menggunakan program consumer promotion dalam bentuk undian berhadiah, premium (diskon), pengujian gratis (sampel), deals, kontes dan hadiah (gift) tujuannya tak lain adalah agar konsumen mengalami respon yang berupa sadar, tertarik, evaluasi, mencoba dan adopsi sehingga akhirnya diharapkan peningkatan respon konsumen untuk menggunakan atau membeli produk yang dipromosikan.

Di bawah ini terdapat gambaran dari paradigma penelitian pengaruh program consumer promotion NSP 1212 Telkomsel terhadap respon konsumen dalam penggunaannya:

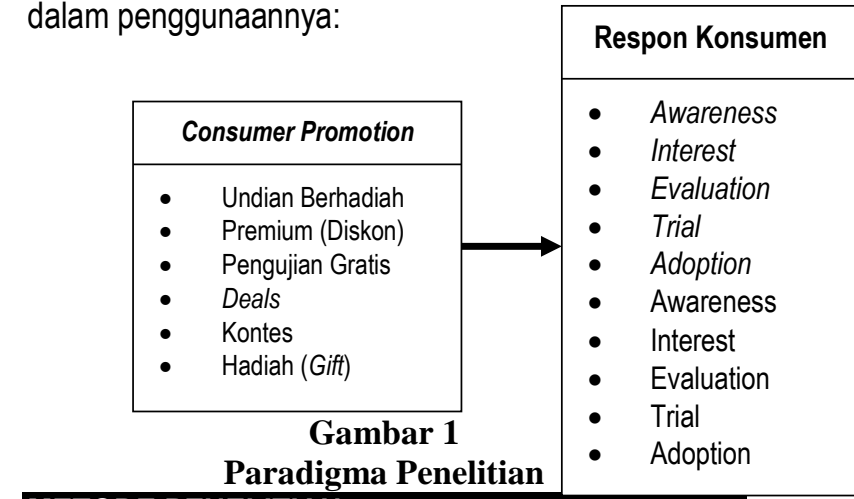

METODE PENELITIAN

Penelitian ini menganalisis mengenai pengaruh Consumer Promotion Nada Sambung Pribadi (NSP) 1212 Telkomsel terhadap respon konsumen dalam penggunannya. Adapun yang menjadi objek 
penelitian sebagai variabel bebas (independent variabel) atau variabel eksogen adalah Consumer Promotion yang meliputi undian, premium (diskon), pengujian gratis, deals, kontes dan hadiah (giff). Objek penelitian sebagai variabel terikat (dependent variabel) atau variabel endogen adalah Respon Konsumen yang meliputi awerness, interest, evaluation, trial and adaption.

Pada penelitian ini yang menjadi responden adalah mahasiswa FPIPS UPI Bandung angkatan 2007 pengguna layanan NSP 1212 berjumlah 973 orang. Pemilihan objek tersebut dikarenakan segmen pelanggan NSP 1212 Telkomsel mayoritas dari kalangan remaja dan komunitas yang menggemari musik, dengan demikian mahasiswa sebagai kalangan remaja lebih mudah untuk dijadikan objek penelitian.

Berdasarkan teknik penarikan sampel secara simple random sampling dan dengan menggunakan rumus Harun Al Rasyid diperoleh sampel sebesar 99 sampel, namun untuk meningkatkan keakuratan maka jumlah sampel yang diteliti ditambah sehingga berjumlah 100 sampel. Data yang digunakan adalah data primer dan sekunder dengan teknik pengumpulan data melalui wawancara, observasi, penyebaran kuesioner dan studi literatur.

Pada penelitian ini digunakan dua jenis analisis yaitu analisis deskriptif dan analisis verifikatif. Analisis deskriptif digunakan untuk melihat faktor penyebab sedangkan analisis kuantitatif menitik beratkan dalam pengungkapan perilaku variabel penelitian. Untuk analisis verifikatif dilakukan pengujian hipotesis dengan menggunakan uji statistik. Dengan menggunakan kombinasi metode analisis tersebut dapat diperoleh generalisasi yang bersifat komprehensif.

Tabel 5 di bawah ini menyajikan data mengenai operasionalisasi variabel penelitian.

Tabel 5

Operasionalisasi Variabel Penelitian

\begin{tabular}{|c|c|c|c|c|c|}
\hline Variabel & Sub variabel & Konsep variabel & Indikator & Ukuran & Skala \\
\hline $\begin{array}{l}\text { Consumer } \\
\text { Promotion } \\
\quad\left(\mathrm{X}_{1}\right)\end{array}$ & & $\begin{array}{l}\text { Consumer promotion adalah promosi yang lebih } \\
\text { difokuskan pada konsumen sebagai sasaran } \\
\text { akhir. } \\
\text { (Frans M. Royan 2004:56) }\end{array}$ & & & \\
\hline & \multirow{4}{*}{$\begin{array}{l}\text { Undian } \\
\text { (sweeptakes) } \\
\left(\mathrm{X}_{1.1}\right)\end{array}$} & \multirow{4}{*}{$\begin{array}{l}\text { Undian adalah Penjualan yang dilakukan dengan } \\
\text { menentukan pemenang berdasarkan kesempatan/ } \\
\text { keberuntungan untuk mendapatkan uang tunai, } \\
\text { perjalanan, atau barang karena membeli atau } \\
\text { menggunakan sesuatu. } \\
\text { (Julians Cummins 2004:264) }\end{array}$} & \multirow[t]{2}{*}{$\begin{array}{l}\text { Tujuan promosi dengan } \\
\text { undian }\end{array}$} & $\begin{array}{l}\text { Tingkat ketepatan dalam mendorong } \\
\text { pembelian }\end{array}$ & Ordinal \\
\hline & & & & $\begin{array}{l}\text { Tingkat ketepatan untuk } \\
\text { meningkatkan frekuensi penggunaan }\end{array}$ & Ordinal \\
\hline & & & $\begin{array}{l}\text { Daya Tarik promosi } \\
\text { dengan undian }\end{array}$ & $\begin{array}{l}\text { Tingkat Daya Tarik promosi dengan } \\
\text { undian }\end{array}$ & Ordinal \\
\hline & & & $\begin{array}{l}\text { Kemudahan untuk } \\
\text { mengikuti program } \\
\text { undian }\end{array}$ & $\begin{array}{l}\text { Tingkat Kemudahan untuk mengikuti } \\
\text { program undian }\end{array}$ & Ordinal \\
\hline & \multirow{5}{*}{$\begin{array}{l}\text { Premium } \\
\text { (diskon) } \\
\left(\mathrm{X}_{1.2}\right)\end{array}$} & \multirow{5}{*}{$\begin{array}{l}\text { Karakter dinamis yang penuh semangat dan } \\
\text { imajinasi yang tinggi dalam melakukan perbedaan } \\
\text { dan inovasi } \\
\text { (Kotler \& Amstrong, 2006:140) }\end{array}$} & \multirow[t]{2}{*}{$\begin{array}{l}\text { Tujuan promosi dengan } \\
\text { premium }\end{array}$} & $\begin{array}{l}\text { Tingkat ketepatan dalam mendorong } \\
\text { pembelian }\end{array}$ & Ordinal \\
\hline & & & & $\begin{array}{l}\text { Tingkat ketepatan untuk } \\
\text { meningkatkan frekuensi penggunaan }\end{array}$ & Ordinal \\
\hline & & & $\begin{array}{l}\text { Daya Tarik promosi } \\
\text { dengan premium }\end{array}$ & Tingkat daya tarik program premium & Ordinal \\
\hline & & & $\begin{array}{l}\text { Kemudahan untuk } \\
\text { mengikuti program } \\
\text { undian }\end{array}$ & $\begin{array}{l}\text { Tingkat Kemudahan untuk mengikuti } \\
\text { program undian }\end{array}$ & Ordinal \\
\hline & & & $\begin{array}{l}\text { Kepuasan pemakaian } \\
\text { setelah promosi dengan } \\
\text { premium }\end{array}$ & $\begin{array}{l}\text { Tingkat Kepuasan pemakaian setelah } \\
\text { promosi dengan premium }\end{array}$ & Ordinal \\
\hline & \multirow{4}{*}{$\begin{array}{l}\text { Pengujian } \\
\text { gratis } \\
\left(\mathrm{X}_{1.3}\right)\end{array}$} & \multirow{4}{*}{$\begin{array}{l}\text { Pengujian gratis adalah promosi untuk mengajak } \\
\text { calon pembeli menguji-coba produk tanpa biaya } \\
\text { dengan harapan mereka akan membeli. } \\
\text { (Julians Cummins 2004:264) }\end{array}$} & \multirow[t]{2}{*}{$\begin{array}{l}\text { Tujuan promosi dengan } \\
\text { pengujian gratis }\end{array}$} & $\begin{array}{l}\text { Tingkat ketepatan dalam mendorong } \\
\text { pembelian }\end{array}$ & Ordinal \\
\hline & & & & $\begin{array}{l}\text { Tingkat ketepatan untuk } \\
\text { meningkatkan frekuensi penggunaan }\end{array}$ & Ordinal \\
\hline & & & $\begin{array}{l}\text { Daya Tarik promosi } \\
\text { dengan pengujian gratis }\end{array}$ & $\begin{array}{l}\text { Tingkat Daya Tarik promosi dengan } \\
\text { pengujian gratis }\end{array}$ & Ordinal \\
\hline & & & $\begin{array}{l}\text { Kemudahan promosi } \\
\text { dengan pengujian gratis }\end{array}$ & $\begin{array}{l}\text { Tingkat Kemudahan promosi dengan } \\
\text { pengujian gratis }\end{array}$ & Ordinal \\
\hline & \multirow[t]{4}{*}{$\begin{array}{l}\text { Deals } \\
\left(X_{1.4}\right)\end{array}$} & \multirow{4}{*}{$\begin{array}{l}\text { Kesepakatan antara produsen dengan konsumen, } \\
\text { biasanya produsen menawarkan produk baru } \\
\text { yang diuji-cobakan pada konsumen secara gratis } \\
\text { dalam beberapa waktu, apabila konsumen } \\
\text { merasa puas atau menyukai produk yang } \\
\text { ditawarkan maka dapat melakukan pembelian } \\
\text { (Julians Cummins 2004:265) }\end{array}$} & \multirow[t]{2}{*}{$\begin{array}{l}\text { Tujuan promosi dengan } \\
\text { deals }\end{array}$} & $\begin{array}{l}\text { Tingkat ketepatan dalam mencoba } \\
\text { produk }\end{array}$ & Ordinal \\
\hline & & & & $\begin{array}{l}\text { Tingkat ketepatan untuk } \\
\text { meningkatkan frekuensi penggunaan }\end{array}$ & Ordinal \\
\hline & & & $\begin{array}{l}\text { Daya Tarik promosi } \\
\text { dengan deals }\end{array}$ & $\begin{array}{l}\text { Tingkat Daya Tarik promosi dengan } \\
\text { deals }\end{array}$ & Ordinal \\
\hline & & & $\begin{array}{l}\text { Kemudahan promosi } \\
\text { dengan deals }\end{array}$ & $\begin{array}{l}\text { Tingkat Kemudahan promosi dengan } \\
\text { deals }\end{array}$ & Ordinal \\
\hline
\end{tabular}

$25-100$

Pengaruh Program Consumer Promotion Nada Sambung Pribadi (NSP) 1212 Telkomsel terhadap Respon Konsumen dalam Penggunaannya 


\section{StrategiC}

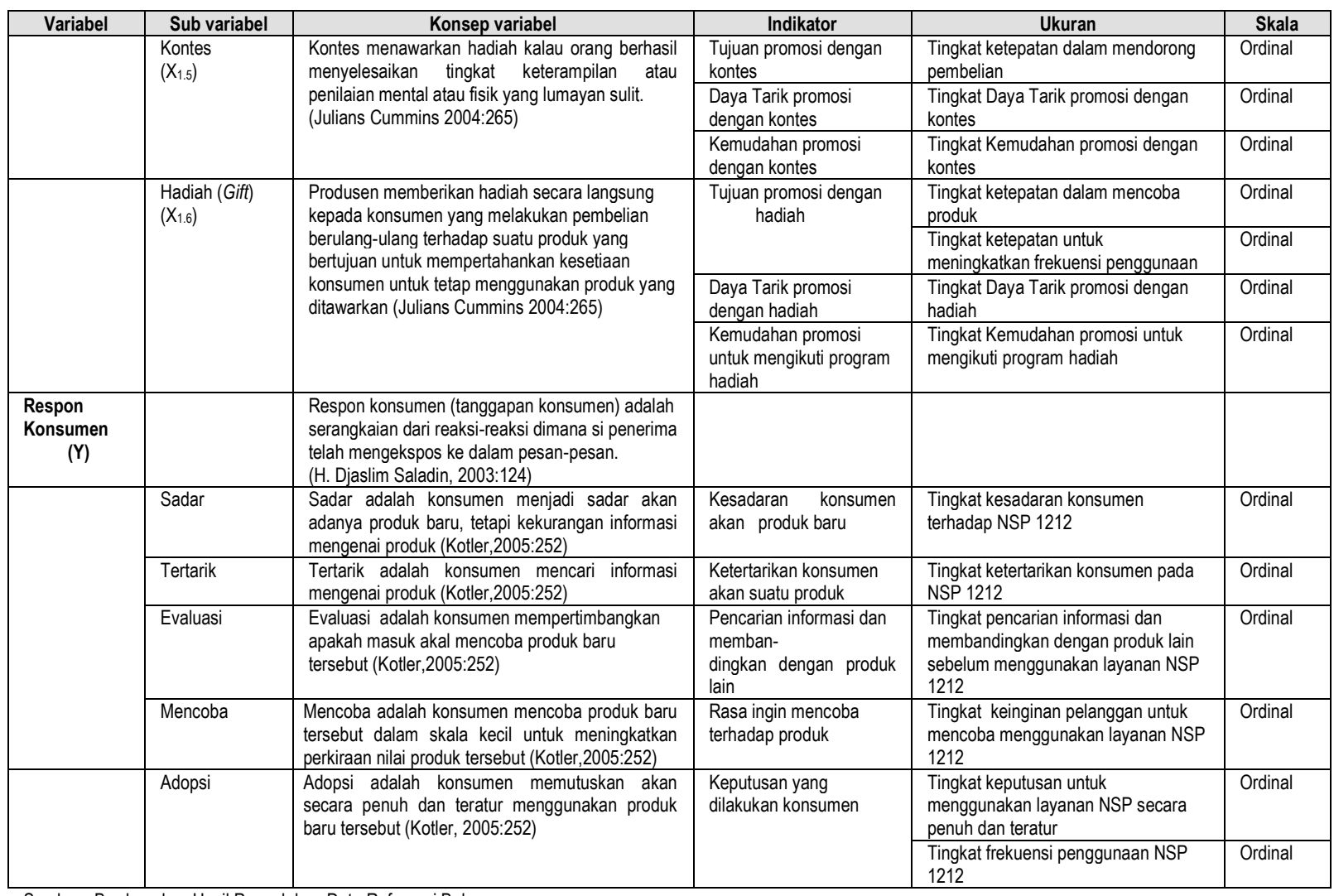

Variabel yang diteliti pada penelitian ini adalah

HASIL PENELITIAN DAN PEMBAHASAN

Hasil penelitian dan pembahasan akan disajikan secara terurut. Dimulai dengan rekapitulasi tanggapan responden terhadap variabel penelitian, kemudian pengujian hipotesis, dan diakhiri dengan penyajian mengenai implikasi penelitian ini terhadap bidang kajian yang diteliti.

\section{REKAPITULASI TANGGAPAN RESPON-DEN TERHADAP VARIABEL PENELITIAN}

consumer promotion yang terdiri dari undian, premium (diskon), pengujian gratis, deals, kontes, dan hadiah. Respon konsumen yang terdiri dari sadar, tertarik, evaluasi, mencoba dan adopsi. Pada penelitian ini diteliti tanggapan responden yang terdiri dari 100 orang mengenai variabel-variabel tersebut melalui penyebaran kuesioner

\section{Variabel Consumer Promotion}

Mari kita simak Tabel 6 yang menyajikan rekapitulasi skor variabel consumer promotion.

Tabel 6

Rekapitulasi Skor Tanggapan Responden terhadap Consumer Promotion

\begin{tabular}{|c|c|c|c|c|c|}
\hline No & Variabel/Dimensi & $\begin{array}{l}\text { Perolehan } \\
\text { Skor }\end{array}$ & Skor Ideal & $\%$ & $\begin{array}{c}\text { Analisis } \\
\text { Frekuensi }\end{array}$ \\
\hline \multirow{6}{*}{1} & Undian & & & & \\
\hline & Tingkat keinginan menggunakan NSP 1212 dengan undian & 307 & 500 & 61,4 & 51,5 \\
\hline & Tingkat frekuensi penggunaan NSP 1212 setelah adanya undian & 287 & 500 & 57,4 & 44,5 \\
\hline & Tingkat kemenarikan program undian & 310 & 500 & 62 & 54,5 \\
\hline & Tingkat kemudahan program undian & 306 & 500 & 61,2 & 51 \\
\hline & Total skor Undian & 1210 & 2000 & 60,5 & 50,37 \\
\hline \multirow{6}{*}{2} & Premium (Diskon) & & & & \\
\hline & Tingkat keinginan menggunakan NSP 1212 dengan premium (diskon & 271 & 500 & 54,2 & 40,5 \\
\hline & Tingkat frekuensi penggunaan NSP 1212 setelah adanya premium (diskon) & 276 & 500 & 55,2 & 42 \\
\hline & Tingkat kemenarikan program premium (diskon) & 300 & 500 & 60 & 50,5 \\
\hline & Tingkat kemudahan program premium (diskon) & 295 & 500 & 59 & 46,5 \\
\hline & Tingkat kepuasan pelanggan menggunakan NSP 1212 setelah adanya premium (diskon) & 283 & 500 & 56,6 & 37 \\
\hline
\end{tabular}




\section{StrategiC}

\begin{tabular}{|c|c|c|c|c|c|}
\hline No & Variabel/Dimensi & $\begin{array}{l}\text { Perolehan } \\
\text { Skor }\end{array}$ & Skor Ideal & $\%$ & $\begin{array}{c}\text { Analisis } \\
\text { Frekuensi }\end{array}$ \\
\hline & Total Skor Premium (Diskon) & 1425 & 2500 & 57 & 43,3 \\
\hline \multirow{6}{*}{3} & Pengujian Gratis & & & & \\
\hline & Tingkat keinginan menggunakan NSP 1212 dengan program deals & 293 & 500 & 58,6 & 47,5 \\
\hline & Tingkat frekuensi penggunaan 292NSP 1212 setelah adanya deals & 287 & 500 & 57,4 & 49 \\
\hline & Tingkat kemenarikan program deals & 289 & 500 & 57,8 & 42,5 \\
\hline & Tingkat kemudahan program deals & 290 & 500 & 58 & 42,5 \\
\hline & Total Skor Deals & 1159 & 2000 & 57,95 & 45,38 \\
\hline \multirow{6}{*}{4} & Deals & & & & \\
\hline & Tingkat keinginan menggunakan NSP 1212 dengan program deals & 293 & 500 & 58,6 & 47,5 \\
\hline & Tingkat frekuensi penggunaan 292NSP 1212 setelah adanya deals & 287 & 500 & 57,4 & 49 \\
\hline & Tingkat kemenarikan program deals & 289 & 500 & 57,8 & 42,5 \\
\hline & Tingkat kemudahan program deals & 290 & 500 & 58 & 42,5 \\
\hline & Total Skor Deals & 1159 & 2000 & 57,95 & 45,38 \\
\hline \multirow{5}{*}{5} & Kontes & & & & \\
\hline & Tingkat keinginan menggunakan NSP 1212 dengan program kontes & 267 & 500 & 53,4 & 35 \\
\hline & Tingkat kemenarikan program kontes & 262 & 500 & 52,4 & 32 \\
\hline & Tingkat kemudahan program kontes & 258 & 500 & 51,6 & 32 \\
\hline & Total Skor Kontes & 787 & 1500 & 52,46 & 33 \\
\hline \multirow{6}{*}{6} & Hadiah (Gift) & & & & \\
\hline & Tingkat keinginan menggunakan NSP 1212 dengan program hadiah (gift) & 302 & 500 & 60,4 & 48,5 \\
\hline & Tingkat frekuensi penggunaan NSP 1212 setelah adanya hadiah (gift) & 283 & 500 & 56,6 & 43,5 \\
\hline & Tingkat kemenarikan program hadiah (gift) & 294 & 500 & 58,8 & 46,5 \\
\hline & Tingkat kemudahan program hadiah (gift) & 282 & 500 & 56,4 & 43,5 \\
\hline & Total Skor Hadiah (Gift) & 1161 & 2000 & 58,05 & 45,5 \\
\hline & Total Skor Consumer Promotion & 6925 & 12000 & 57,71 & 43,74 \\
\hline
\end{tabular}

Sumber: Berdasarkan Hasil Pengolahan Data 2008

Hasil tersebut menunjukkan bahwa indikator undian yang diselenggarakan oleh Telkomsel mendapat respon yang cukup baik karena program undian mampu mempengaruhi konsumen untuk menggunakan NSP 1212 serta meningkatkan frekuensi penggunaannya, sebab konsumen dituntut untuk terus menggunakan NSP agar kesempatan untuk menang besar, selain itu program undian juga menawarkan hadiah-hadiah yang menarik dan mudah untuk diikuti, sehingga lebih cepat mendapat respon dan perhatian konsumen. Hal tersebut senada dengan Julian Cummin dan Roddy Mullin (2004:265), bahwa: "Undian sangat efektif dalam menimbulkan minat, kesadaran dan partisipasi serta merupakan cara yang cepat dan mudah mengembangkan basis data konsumen dan calon konsumen". Adapun indikator yang dinilai dalam undian adalah dengan program undian ingin menggunakan NSP 1212, dengan undian meningkatkan frekuensi penggunaan NSP 1212, tingkat kemenarikan program undian dan tingkat kemudahan program undian.

\section{Variabel Respon Konsumen}

Tabel 7 di bawah ini menyajikan data hasil rekapitulasi skor variabel respon konsumen.

Rekapitulasi Skor Tanggapan Responden terhadap Respon Konsumen

\begin{tabular}{|c|c|c|c|c|c|}
\hline No & Variabel/Dimensi & Perolehan Skor & Skor Ideal & $\%$ & $\begin{array}{l}\text { Analisis } \\
\text { Frekuensi }\end{array}$ \\
\hline \multirow{2}{*}{1} & Sadar & & & & \\
\hline & Tingkat kesadaran konsumen pada layanan NSP 1212 & 290 & 500 & 58 & 46 \\
\hline \multirow{2}{*}{2} & Tertarik & & & & \\
\hline & Tingkat ketertarikan konsumen pada layanan NSP 1212 & 287 & 500 & 57,4 & 45 \\
\hline \multirow[b]{2}{*}{3} & Evaluasi & & & & \\
\hline & $\begin{array}{l}\text { Tingkat keinginan menggunakan NSP } 1212 \text { dengan } \\
\text { pengujian gratis }\end{array}$ & 283 & 500 & 56,6 & 40,5 \\
\hline \multirow{6}{*}{4} & Mencoba & & & & \\
\hline & $\begin{array}{l}\text { Tingkat keinginan konsumen untuk mencoba layanan NSP } \\
1212\end{array}$ & 277 & 500 & 55,4 & 39,5 \\
\hline & Adopsi & & & & \\
\hline & $\begin{array}{l}\text { Tingkat keinginan untuk memutuskan menggunakan NSP } \\
1212 \text { secara penuh dan teratur }\end{array}$ & 268 & 500 & 53,6 & 34,5 \\
\hline & $\begin{array}{l}\text { Tingkat frekuensi keteraturan konsumen menggunakan } \\
\text { NSP } 1212 \text { selama ini }\end{array}$ & 271 & 500 & 54,2 & 36 \\
\hline & Total Skor Respon Konsumen & 1676 & 3000 & 55,86 & 40,25 \\
\hline
\end{tabular}




\begin{tabular}{|l|l|l|l|l|}
\hline No & Variabel/Dimensi & Perolehan Skor & Skor Ideal & $\%$ \\
\hline
\end{tabular}

Sumber: Berdasarkan Hasil Pengolahan Data 2008

Berdasarkan Tabel 7 di atas tingkat kesadaran konsumen pada layanan NSP 1212 dibandingkan dengan skor ideal memperoleh skor tertinggi yaitu sebesar 290 atau sekitar 58\% termasuk dalam kategori sedang, hal ini dikarenakan kejelasan informasi yang diberikan oleh Telkomsel kepada konsumen mengenai layanan NSP 1212.

Tingkat keinginan untuk memutuskan menggunakan NSP 1212 secara penuh dan teratur memperoleh skor terendah dibandingkan dengan skor ideal yaitu sebesar 268 atau sekitar 53,6\% termasuk dalam kategori sedang, hal ini dikarenakan banyaknya pertimbangan yang dilakukan oleh konsumen untuk mengadopsi produk baru, sehingga Telkomsel harus bisa memperkenalkan layanan NSP 1212 secara mendalam mengenai kelebihannya, content lagu yang ditawarkan dan sebagainya. Selain itu konsumen harus dimudahkan untuk menggunakan layanan NSP dengan cara meningkatkan kualitas pelayanan jasanya pada konsumen.

Gambaran tingkat respon konsumen secara keseluruhan dinilai cukup kuat yaitu sebesar 55,86\% dan secara berurutan dapat diketahui indikatorindikator dan ukuran yang dominan. Indikator yang paling dominan adalah pada tahap sadar akan adanya NSP 1212 sebesar 58\%, indikator tertinggi kedua adalah pada tahap tertarik menggunakan NSP 1212 yaitu sebesar $57,4 \%$, dan indikator terendah adalah pada tahap adopsi pada tingkat keinginan untuk memutuskan menggunakan NSP 1212 secara penuh dan teratur sebesar $34,5 \%$.

Hasil tersebut menunjukkan bahwa tingkat kesadaran konsumen ini dipengaruhi oleh kejelasan informasi yang diberikan oleh Telkomsel mengenai layanan NSP 1212 tentang manfaat fitur NSP serta bagaimana cara mengaplikasikannya sementara tingkat ketertarikan konsumen dipengaruhi oleh keinginan kuat konsumen mencari informasi mengenai layanan NSP 1212 karena kebutuhan konsumen akan layanan NSP 1212. maka dari pada itu Telkomsel harus lebih memudahkan akses konsumennya untuk mengetahui secara jelas mengenai layanan NSP 1212.

Sedangkan yang termasuk ke dalam indikator terendah yaitu pada tahap adopsi pada tingkat keinginan untuk memutuskan menggunakan NSP 1212 secara penuh dan teratur, karena biasanya konsumen mempertimbangkan beberapa hal untuk memutuskan mengadopsi suatu produk baru. Hal ini perlu dievaluasi kembali oleh Telkomsel dengan cara menetapkan respon apa yang diinginkan, sehingga dapat menjalin hubungan dengan konsumennya agar mengadopsi produk baru yang ditawarkan.

Tabel 8 di bawah ini menyajikan data mengenai matrk korelasi dimensi consumer promotion dengan respon konsumen.

Tabel 8

Matrik Korelasi antara Dimensi Consumer Promotion dengan Loyalitas Respon Konsumen

\begin{tabular}{|c|c|c|c|c|c|c|c|}
\hline & $\mathbf{Y}$ & $\mathbf{X}_{1.1}$ & $\mathbf{X}_{1.2}$ & $\mathbf{X}_{1.3}$ & $\mathbf{X}_{1.4}$ & $\mathbf{X}_{1.5}$ & $\mathbf{X}_{1.6}$ \\
\hline $\mathbf{Y}$ & 1,000 & 0,540 & 0,512 & 0,424 & 0,312 & 0,256 & 0,384 \\
\hline $\mathbf{X}_{1.1}$ & 0,540 & 1,000 & 0,583 & 0,271 & 0,367 & 0,215 & 0,342 \\
\hline $\mathbf{X}_{1.2}$ & 0,512 & 0,583 & 1,000 & 0,421 & 0,173 & 0,129 & 0,213 \\
\hline $\mathbf{X}_{1.3}$ & 0,427 & 0,271 & 0,421 & 1,000 & 0,152 & 0,243 & 0,018 \\
\hline $\mathbf{X}_{1.4}$ & 0,312 & 0,367 & 0,173 & 0,152 & 1,000 & 0,124 & 0,119 \\
\hline $\mathbf{X}_{1.5}$ & 0,256 & 0,215 & 0,129 & 0,243 & 0,124 & 1,000 & 0,064 \\
\hline $\mathbf{X}_{1.6}$ & 0,384 & 0,342 & 0,213 & 0,018 & 0,119 & 0,064 & 1,000 \\
\hline
\end{tabular}

Sumber: Hasil pengolahan Data 2008

Berdasarkan hasil pengujian hipotesis diketahui bahwa korelasi terbesar antara setiap dimensi $X$ dengan $Y$ diperoleh undian sebagai $\left(X_{1.1}\right)$ dan Respon konsumen sebagai $(Y)$ dengan nilai 0,540 . Berdasarkan interprestasi koefisien korelasi menunjukan bahwa terdapat hubungan yang signifikan antara dimensi undian dengan respon konsumen. Hal tersebut senada dengan Julian Cummin dan Roddy Mullin (2004:265), bahwa: "Undian sangat efektif dalam menimbulkan minat, kesadaran dan partisipasi serta merupakan cara yang cepat dan mudah mengembangkan basis data konsumen dan calon konsumen".

Sedangkan nilai koefisien korelasi terbesar antar setiap dimensi $X$ dimiliki oleh undian $\left(X_{1.1}\right)$ dan premium (diskon) $\left(X_{1.2}\right)$ dengan nilai 0,583 . Hal tersebut menunjukan bahwa terdapat hubungan yang signifikan antara undian dengan premium (diskon). Sementara korelasi terkecil antara setiap dimensi $X$ dengan $Y$ diperoleh kontes sebagai $\left(X_{1.5}\right)$ dan Respon konsumen sebagai $(Y)$ dengan nilai 0,256.

Selain itu kontes sebagai $\left(X_{1.5}\right)$ mempunyai korelasi kecil apabila dihubungkan dengan variabel $X$ lain, pengaruh tidak langsung terhadap undian $\left(X_{1.1}\right)$ dengan nilai 0,215 , terhadap premium $\left(X_{1.2}\right)$ dengan nilai 0,129 , terhadap pengujian gratis $\left(X_{1.3}\right)$ dengan 
nilai 0,243 , terhadap deals $\left(X_{1.4}\right)$ dengan nilai 0,124 dan terhadap hadiah $\left(X_{1.6}\right)$ dengan nilai 0,064 .

Hal tersebut menunjukan bahwa kontes mempunyai pengaruh yang kecil terhadap respon konsumen. Sesuai dengan pendapat Julian Cummins dan Roddy Mullin (2004:254) bahwa; "Kontes menawarkan hadiah kalau orang berhasil menyelesaikan tingkat keterampilan atau penilaian mental atau fisik yang lumayan sulit. Peserta mungkin akan diminta membayar atau melakukan pembelian untuk mengikutinya". Sehingga banyak konsumen yang tidak memiliki keahlian enggan untuk terlibat di dalamnya.

Kontes ini perlu diadakan oleh Telkomsel karena wujud kepedulian Telkomsel terhadap insan musik sehingga dapat mengapresiasikan keterampilannya dalam bermusik untuk membuat Nada Sambung Pribadi, tapi dalam hal ini konsumen yang mempunyai keterampilan saja yang dapat terlibat langsung di dalamnya.

Berdasarkan hasil pengujian untuk uji $\mathrm{F}$ melalui program SPSS 12.0 diperoleh data pengujian keseluruhan pada Tabel Anova menunjukkan tingkat signifikan pada model ke-1, yang menunjukkan $F_{\text {hitung }}$ $>F_{\text {tabel, }}$ yaitu 63,208> 2,709 dengan tingkat signifikan (sig) sama dengan 0,000. atau lebih kecil dari 0,05, sehingga dapat diambil kesimpulan Ho ditolak oleh karena itu pengujian secara individual dapat dilakukan.

Selanjutnya adalah pengujian secara individual dengan melihat koefisien korelasi jalur $X$ terhdap $Y$ dengan menggunakan program SPSS 12.0 diperoleh ouput koefisien jalur. Adapun untuk pengujian koefisien jalur setiap variabel diperoleh dalam Tabel 9 berikut ini:

Tabel 9

Hasil Pengujian Koefisien Jalur

\begin{tabular}{|c|c|c|c|c|}
\hline \multicolumn{2}{|c|}{ Koefisien Jalur } & thitung & $t_{\text {tabel }}$ & Kesimpulan \\
\hline$P X_{1.1}$ & 0,327 & 3,205 & 1,988 & Ho Ditolak \\
\hline $\mathrm{PYX}_{1.2}$ & 0,289 & 2,632 & 1,988 & Ho Ditolak \\
\hline $\mathrm{PYX}_{1.3}$ & 0,231 & 2,447 & 1,988 & Ho Ditolak \\
\hline $\mathrm{PYX}_{1.4}$ & 0,174 & 2,114 & 1,988 & Ho Ditolak \\
\hline $\mathrm{PYX}_{1.5}$ & 0,125 & 2,092 & 1,988 & Ho Ditolak \\
\hline PYX $_{1.6}$ & 0,197 & 2,213 & 1,988 & Ho Ditolak \\
\hline
\end{tabular}

Sumber : Hasil Pengolahan Data 2008

Berdasarkan hasil pengujian koefisien jalur diperoleh pengaruh undian terhadap respon konsumen memiliki nilai 0,327 , pengaruh premium (diskon) terhadap respon konsumen memiliki nilai 0,289 , pengaruh pengujian gratis terhadap respon konsumen memiliki nilai 0,231 , pengaruh deals terhadap respon konsumen memiliki nilai 0,174, pengaruh kontes terhadap respon konsumen memiliki nilai 0,125 , pengaruh hadiah terhadap respon konsumen memiliki nilai 0,197 . Pengaruh terbesar ada pada pengaruh undian terhadap respon konsumen. $t$ hitung yang diperoleh dengan tingkat signifikansi 0.00 yaitu $3,205,2,632,2,4472,114$, 2,092, dan 2,213 dengan $t$ tabel 1,998 jadi dapat disimpulkan bahwa Ho ditolak yang artinya terdapat pengaruh pengaruh consumer promotion terhadap respon konsumen.

Hasil pengujian seluruh pengaruh brand personality terhadap loyalitas pelanggan disajikan pada Tabel 10 sebagai berikut.

Tabel 10

Hasil Pengujian Pengaruh Consumer Promotion Terhadap Respon Konsumen

\begin{tabular}{|c|c|c|c|c|}
\hline $\begin{array}{l}\text { Pengaruh } \\
\text { Variabel }\end{array}$ & $\begin{array}{c}\text { Koefisien } \\
\text { Jalur }\end{array}$ & $\begin{array}{l}\text { Pengaruh } \\
\text { Langsung }\end{array}$ & $\begin{array}{c}\mathbf{R}^{2} \mathbf{Y} \mathbf{X}_{1.1} \\
\ldots, Y \mathbf{X}_{1.6}\end{array}$ & $\begin{array}{l}\text { Pengujian } \\
\text { Hipotesis }\end{array}$ \\
\hline $\mathrm{X}_{1.1}$ terhadap $\mathrm{Y}$ & 0,321 & 0,1069 & 0,2062 & Ho Ditolak \\
\hline$X_{1.2}$ terhadap $Y$ & 0,289 & 0,0835 & 0,2053 & Ho Ditolak \\
\hline $\mathrm{X}_{1.3}$ terhadap $\mathrm{Y}$ & 0,231 & 0.0533 & 0,1212 & Ho Ditolak \\
\hline $\mathrm{X}_{1.4}$ terhadap $\mathrm{Y}$ & 0,171 & 0,0302 & 0,0723 & Ho Ditolak \\
\hline $\mathrm{X}_{1.5}$ terhadap $Y$ & 0,125 & 0,0156 & 0,0400 & Ho Ditolak \\
\hline $\mathrm{X}_{1.6}$ terhadap $\mathrm{Y}$ & 0,197 & 0,0388 & 0,0015 & Ho Ditolak \\
\hline \multicolumn{3}{|l|}{$\mathbf{R}^{2}$} & 0,7242 & \\
\hline
\end{tabular}

Sumber : Hasil Pengolahan Data 2008

Berdasarkan hasil perhitungan diatas maka pengaruh consumer promotion termasuk kategori kuat, untuk koefisien jalur variabel lainnya diluar variabel $\mathrm{X}_{1.1}, \mathrm{X}_{1.2}, \mathrm{X}_{1.3}, \mathrm{X}_{1.4}, \mathrm{X}_{1.5}$, dan $\mathrm{X}_{1.6}$ ditentukan melalui:

Artinya $X_{1.1}, X_{1.2}, X_{1.3}, X_{1.4}, X_{1.5}$, dan $X_{1.6}$ secara bersama-sama mempengaruhi $Y$ adalah $72,42 \%$ dan sisanya sebesar $(0,5252)^{2}=0,2758 \times 100 \%=$ $27,58 \%$ dipengaruhi oleh faktor lain yang tidak termasuk dalam penelitian. Misalnya product, price, place, people, process, dan phissical evidence yang tidak termasuk ke dalam penelitian

Berdasarkan Tabel 10 dapat dilihat nilai pengaruh langsung dari $X$ terhadap $Y$, nilai pengaruh tidak langsung, nilai total pengaruh dan nilai thitung terhadap alpha dengan tingkat kesalahan 0,05 sehingga dapat disimpulkan keseluruhan Ho ditolak dan Ha diterima. Sehingga disimpulkan bahwa adanya pengaruh consumer promotion terhadap respon konsumen sampo Sunsilk. 


\section{StrategiC}

Tabel 11

Hasil Pengujian Koefisien Jalur Pengaruh Langsung dan Tidak Langsung Dimensi Variabel $X$ terhadap $Y$

\begin{tabular}{|c|c|c|c|c|c|c|c|c|c|c|c|}
\hline \multirow{2}{*}{$X$} & \multirow{2}{*}{$\begin{array}{c}\text { Pengaruh } \\
\text { Langsung } \\
\text { Terhadap } \\
\mathbf{Y} \\
\end{array}$} & \multicolumn{6}{|c|}{ Pengaruh Tidak Langsung } & \multirow{2}{*}{$\begin{array}{c}\text { Total } \\
\text { Pengaruh }\end{array}$} & \multirow{2}{*}{$\begin{array}{c}\mathrm{t} \text { tabel } \\
1,988 \\
\mathrm{t} \text { hitung }\end{array}$} & \multirow{2}{*}{$\begin{array}{c}\text { Sign } \\
\text { Alpha } \\
0,05\end{array}$} & \multirow{2}{*}{ Kepu-tusan } \\
\hline & & $\mathbf{X}_{1.1}$ & $\mathbf{X}_{1.2}$ & $\mathbf{X}_{1.3}$ & $\mathbf{X}_{1.4}$ & $\mathbf{X}_{1.5}$ & $\mathbf{X}_{1.6}$ & & & & \\
\hline$X_{1.1}$ & 0,1069 & 1,000 & 0,0550 & 0,0204 & 0,0208 & 0,0087 & 0,0220 & 0,2062 & 3,205 & 1.988 & Ho Ditolak \\
\hline $\mathrm{X}_{1.2}$ & 0,0835 & 0,0550 & 1,000 & 0,0281 & 0,0086 & 0,0046 & 0,0121 & 0,2053 & 2,632 & 1.988 & Ho Ditolak \\
\hline $\mathrm{X}_{1.3}$ & 0,0533 & 0,0204 & 0,0281 & 1,000 & 0,0061 & 0,0070 & 0,0008 & 0,1212 & 2,447 & 1.988 & Ho Ditolak \\
\hline $\mathrm{X}_{1.4}$ & 0,0302 & 0,0209 & 0,0189 & 0,0061 & 1,000 & 0,0026 & 0,0040 & 0,0723 & 2,114 & 1.988 & Ho Ditolak \\
\hline $\mathrm{X}_{1.5}$ & 0,0156 & 0,0088 & 0,0077 & 0,0037 & 0,0026 & 1,000 & 0,0015 & 0,0400 & 2,092 & 1.988 & Ho Ditolak \\
\hline $\mathrm{X}_{1.6}$ & 0,0388 & 0,0220 & 00121 & 0,0096 & 0,0040 & 0,0015 & 1,000 & 0,0792 & 2,213 & 1.988 & Ho Ditolak \\
\hline & & & & & & & & $R^{2}=0,7242$ & & & \\
\hline
\end{tabular}

Sumber: Hasil Pengolahan Data 2008

Artinya $X_{1.1}, X_{1.2}, X_{1.3}, X_{1.4}, X_{1.5}$ dan $X_{1.6}$ secara bersama-sama mempengaruhi $Y$ adalah $72,42 \%$ dan sisanya sebesar $(0,5252)^{2}=0,2758 \times 100 \%=$ $27,58 \%$ dipengaruhi faktor lain seperti product, price, place, people, process, phissical evidence dan customer service yang tidak termasuk ke dalam penelitian.

Berdasarkan data pada Tabel 10 dapat diambil kesimpulan terdapat pengaruh consumer promotion terhadap respon pelanggan. Dapat dilihat nilai pengaruh langsung dari $X$ terhadap $Y$, nilai pengaruh tidak langsung, nilai total pengaruh dan nilai thitung terhadap alpha dengan tingkat kesalahan 0,05 sehingga dapat disimpulkan keseluruhan Ho ditolak dan $\mathrm{Ha}$ diterima.

Berdasarkan data yang disajikan pada Tabel 11 dapat dilihat hasil pengolahan analisis path mengenai pengaruh consumer promotion terhadap respon konsumen. Dapat dilihat nilai pengaruh langsung dari $X$ terhadap $Y$, nilai pengaruh tidak langsung, nilai total pengaruh dan nilai $t$ nitung terhadap alpha dengan tingkat kesalahan 0.05 dapat disimpulkan keseluruhan $\mathrm{Ho}$ ditolak dan $\mathrm{Hi}$ diterima. Sehingga disimpulkan bahwa adanya pengaruh consumer promotion NSP 1212 terhadap respon konsumen dalam penggunaannya.

Dimensi $X_{1.1}, X_{1.2}, X_{1.3}, X_{1.4}, X_{1.5}$, dan $X_{1.6}$ dinyatakan signifikan karena nilai thitung lebih besar dari tabel dengan masing-masing nilai $3,205,2,632$, $2,447,2,114,2,092$, dan 2,213 dengan nilai $t_{\text {tabel }}$ 1,988 , sehingga keputusan untuk $X_{1.1}, X_{1.2}, X_{1.3}, X_{1.4}$, $X_{1.5}$, dan $X_{1.6}$ Ho ditolak. Hal ini menyatakan bahwa dimensi undian, premium (diskon), pengujian gratis, deals, kontes dan hadiah (gift) NSP 1212 berpengaruh terhadap respon konsumen dalam penggunaannya.

\section{IMPLIKASI HASIL PENELITIAN}

Berdasarkan hasil penelitian mengenai pengaruh consumer promotion terhadap respon konsumen, dihasilkan temuan-temuan empirik sebagai berikut:

1. Hasil penelitian, pembahasan hasil perhitungan dimensi variabel consumer promotion NSP 1212 adalah sebagai berikut:

Dimensi undian menjadi dimensi dari variabel consumer promotion yang paling tinggi mempengaruhi respon konsumen dalam penggunaaan NSP 1212, hal ini dikarenakan undian yang diselenggarakan oleh Telkomsel dengan hadiah-hadiah yang ditawarkannya menarik dan mudah untuk diikuti, sehingga lebih cepat mendapat respon dan perhatian konsumen. Hal tersebut senada dengan Julian Cummin dan Roddy Mullin (2004:265), bahwa: "Undian sangat efektif dalam menimbulkan minat, kesadaran dan partisipasi serta merupakan cara yang cepat dan mudah mengembangkan basis data konsumen dan calon konsumen". Indikator undian ini terdiri dari ketepatan program undian dalam mendorong penggunaan NSP 1212, tingkat frekuensi penggunaan NSP 1212 dengan adanya NSP 1212, kemenarikan program undian dan kemudahan mengikuti program undian.

Dimensi kontes merupakan dimensi dari variabel consumer promotion yang paling rendah dalam mempengaruhi respon konsumen dalam penggunaan NSP 1212, hal ini dikarenakan pada program kontes diperlukan keterampilan yang tidak semua memilikinya sehingga orang malas untuk mengikutinya, tak hanya itu peserta kemungkinan akan diminta membayar atau melakukan pembelian untuk mengikutinya. Indikator dimensi kontes meliputi ketepatan program kontes dalam mendorong penggunaan NSP 1212, kemenarikan program undian dan kemudahan mengikuti program undian. 
2. Tanggapan responden terhadap respon konsumen yang terdiri dari sadar, tertarik, evaluasi, mencoba dan adopsi secara umum sudah baik. Tanggapan responden pada dimensi sadar yaitu kesadaran konsumen pada layanan NSP 1212 merupakan dimensi yang memperoleh skor yang lebih tinggi, hal ini dikarenakan kejelasan informasi yang diberikan oleh Telkomsel kepada konsumen mengenai layanan NSP 1212. Sedangkan tanggapan responden pada dimensi adopsi yatu keinginan untuk memutuskan menggunakan NSP 1212 secara penuh dan teratur, mendapatkan skor yang paling rendah dari dimensi-dimensi lainnya, hal ini dikarenakan banyaknya pertimbangan yang dilakukan oleh konsumen untuk mengadopsi produk baru.

3. Pengaruh Consumer Promotion terhadap Respon Konsumen. Berdasarkan penelitian secara empirik diperoleh keterangan bahwa consumer promotion yang dilaksanakan NSP 1212 Telkomsel mempunyai pengaruh yang positif dan signifikan terhadap respon konsumen dalam penggunaannya. Hal ini terbukti dengan hasil pengujian dapat diketahui bahwa signifikansi variabel consumer promotion 0,000, 0,000 lebih kecil dari 0,05 , hal tersebut berarti bahwa Ho ditolak. Selain berdasarkan koefisien korelasi, pengujian dapat dilakukan dengan membandingkan nilai $t_{\text {tabel }}$ dengan $t_{\text {hitung }}$ untuk $\alpha=$ 0,05 , hasil pengolahan data menunjukan bahwa $t_{\text {hitung }}$ dari variabel adalah 14,703 lebih besar dari tabel yaitu 1,988 dengan demikian Ho ditolak.

Hasil pengujian signifikansi koefisien korelasi serta uji-t menyatakan bahwa Ho ditolak. Artinya terdapat pengaruh yang positif dan signifikan antara consumer promotion terhadap respon konsumen.

Pemaparan di atas sesuai dengan pendapat Stewart H. Rewoldt, James D. Scott dan Martin R. Marshaw (2005:174) "Promosi kepada konsumen akhir mempunyai tujuan merangsang tanggapan atau respon pembeli secara cepat (quick buying response). Sales promotion lebih cepat mempengaruhi konsumen sadar terhadap suatu produk dibandingkan dengan iklan".

Berdasarkan perhitungan diketahui bahwa pengaruh consumer promotion terhadap respon konsumen adalah sebesar $72,42 \%$ dan sisanya sebesar $27,58 \%$ dipengaruhi oleh faktor lain yang tidak termasuk ke dalam penelitian ini.

\section{SIMPULAN DAN SARAN}

Berdasarkan hasil penelitian yang dilakukan oleh peneliti, dapat diambil kesimpulan sebagai berikut:

1. Gambaran mengenai Consumer Promotion NSP 1212 Telkomsel secara keseluruhan dinilai cukup oleh responden. Consumer Promotion NSP 1212 Telkomsel terdiri dari enam dimensi, yaitu undian, premium (diskon), pengujian gratis, deals, kontes dan hadiah (gift). Tanggapan responden terhadap Consu-mer Promotion pada dimensi undian ditinjau dari kemenarikan program undian merupakan dimensi yang paling tinggi mendapatkan skor, hal tersebut dikarenakan Telkomsel gencar memperkenalkan program undian kepada konsumen untuk mengaktifkan NSP-nya dan ditunjang oleh hadiah yang menarik. Sedang-kan perolehan hasil pada dimensi kontes, mendapatkan skor yang paling rendah dari dimensi-dimensi lainnya, hal ini dikarenakan program kontes tidak mudah diikuti karena tidak semua orang dapat mengikuti program ini dan juga syarat-syaratnya yang cukup sulit.

2. Gambaran respon konsumen yang terdiri dari sadar, tertarik, evaluasi, mencoba dan adopsi secara umum dinilai cukup oleh responden. Tanggapan responden pada dimensi sadar yaitu kesadaran konsumen pada layanan NSP 1212 merupakan dimensi yang memperoleh skor yang lebih tinggi, hal ini dikarenakan kejelasan informasi yang diberikan oleh Telkomsel kepada konsumen mengenai laya-nan NSP 1212. Sedangkan tanggapan respon-den pada dimensi adopsi yatu keinginan untuk memutuskan menggunakan NSP 1212 secara penuh dan teratur, mendapatkan skor yang paling rendah dari dimensi-dimensi lainnya, hal ini dikarenakan banyaknya pertimbangan yang dilakukan oleh konsumen untuk mengadopsi produk baru.

3. Pengaruh Consumer Promotion (X) NSP 1212 Telkomsel terhadap respon konsumen $(\mathrm{Y})$ dalam penggunaannya berada pada kategori kuat.

\section{Saran}

Berdasarkan hasil penelitian, maka penulis memberikan beberapa saran mengenai consumer promotion agar dapat meningkatkan respon konsumen dalam penggunannya, yaitu:

1. Consumer Promotion merupakan salah satu strategi Telkomsel untuk meningkatkan respon pelanggannya pada layanan yang dimilikinya yaitu NSP 1212 adapun program consumer 
promotion tersebut yaitu undian, premium (diskon), pengujian gratis, deals, kontes dan hadiah (gift), program-program yang ditawarkan haruslah menarik dan mudah untuk diikuti sehingga konsumen akan terlibat di dalamnya. Berdasarkan penelitian, dimensi kontes memiliki tanggapan paling rendah, hal tersebut dikarenakan cara mengikutinya yang tidak mudah, di mana hanya orang-orang yang memiliki keterampilan saja yang dapat mengikuti program kontes. Oleh karena itu Telkomsel harus dapat melibatkan seluruh pelanggannya untuk dapat mengikuti program-program promosinya. Dimensi hadiah memiliki tanggapan cukup, hal tersebut dikarenakan syarat memenangkan hadiah 1 buah NSP, konsumen diharuskan mengaktifkan NSP selama 2 bulan berturut-turut, di mana konsumen yang umumnya remaja ratarata menghabiskan pulsanya untuk layanan sms dan telepon. Oleh sebab itu Telkomsel harus memberikan hadiah yang bersifat kemenangan langsung, sehingga konsumen tidak perlu diminta membayar atau melakukan pembelian untuk mengikutinya. Dimensi deals memiliki tanggapan cukup oleh responden, hal tersebut dikarenakan konsep kesepakatannya yang rumit, di mana konsumen ditawari memperoleh NSP gratis selama 7 hari, apabila ingin dilanjutkan dapat melakukan pembelian dan bila tidaka dapat dilakukan pembatalan. Lagu yang ditawarkan telah ditetapkan oleh Telkomsel sehingga konsumen kurang menyukainya. Oleh karena itu Telkomsel harus lebih memberikan kesempatan yang bebas kepada konsumennya untuk memilih lagu yang disukainya. Dimensi premium memperoleh tanggapan cukup, hal tersebut dikarenakan lagu yang ditawarkan telah ditentukan oleh Telkomsel, sehingga kebanyakan lagu tidak disukai oleh konsumen. Oleh karena itu Telkomsel harus lebih memberikan pilihan yang beragam atau lagu-lagu yang sedang hits sehingga konsumen tertarik untuk menggunakan NSP 1212. Dimensi pengujian gratis memperoleh tanggapan cukup, hal tersebut dikarenakan pengujian gratis diadakan pada even-even tertentu di mana Telkomsel jarang memberikan informasi kepada konsumennya mengenai NSP gratis yang hanya diberitahukan apabila konsumen mendown-load nya melalui internet. Oleh karena itu Telkomsel harus lebih menginformasikan lagi mengenai program pengujian gratis kepada konsumennya, sehingga dengan informasi yang jelas konsumen merasa tertarik untuk kemudian menggunakan NSP. Sementara dimensi undian memperoleh tanggapan yang paling tinggi dengan skor cukup, hal tersebut harus menjadi perhatian Telkomsel, karena program undian menjadi ujung tombak keberhasilan program consumer promotion untuk memperoleh respon dari konsumen. Secara keseluruhan consumer promotion memperoleh tanggapan yang cukup dari responden. Oleh karena itu Telkomsel harus dapat mempertahankannya dan mengevaluasi kembali program-program yang dirasakan memperoleh tanggapan yang rendah.

2. Mengenai respon konsumen dalam penggunaan NSP 1212 dari lima dimensinya yaitu sadar, tertarik, evaluasi, mencoba dan adopsi, dimensi adopsi yaitu keinginan untuk memutuskan menggunakan NSP 1212 secara penuh dan teratur, mendapatkan skor yang paling rendah dari dimensi-dimensi lainnya, hal ini dikarenakan banyaknya pertimbangan yang dilakukan oleh konsumen untuk mengadopsi produk baru oleh karena itu Telkomsel harus lebih gencar lagi mengenalkan layanan NSP serta kemudahan pelayanan untuk menggu-nakannya agar konsumen mengadopsi produk baru yang ditawarkan. Dimensi mecoba memperoleh tanggapan cukup, hal tersebut menunjukan bahwa pengenalan produk layanan NSP 1212 yang dilakukan Telkomsel kurang mengena pada konsumen sehingga konsumen tidak terlalu merasakan seberapa penting layanan tersebut karena layanan NSP hanya berupa prestise bagi sebagian konsumen yang mementingkan gaya atau life style. Telkomsel dituntut untuk lebih bisa memperkenalkan NSP 1212 tidak hanya dengan cara mengiklankan saja. Dimensi evaluasi memperoleh tanggapan cukup, hal ini mengindikasikan bahwa konsumen akan mencari tahu dengan cara menanyakannya pada orang lain tentang manfaat layanan NSP serta cara untuk menggunakannya. Oleh karena itu Telkomsel harus lebih secara nyata menjelaskan manfaat yang dapat diperoleh apabila menggunakan NSP 1212. Dimensi tertarik memperoleh tanggapan cukup, hal ini dipengaruhi oleh sulitnya mencari informasi mengenai layanan NSP 1212, konsumen biasanya menyukai hal-hal yang mudah dan 


\section{StrategiC}

cepat maka dari pada itu Telkomsel harus lebih menginformasikan lagi secara gencar kepada konsumennya tentang kelebihan layanan NSP 1212 serta cara mengaplikasikannya, terakhir dimensi sadar memperoleh tanggapan cukup, hal tersebut dikarenakan tingkat kesadaran akan adanya suatu produk baru pada setiap konsumen berbeda-beda, hal ini dipengaruhi oleh pengetahuan konsumen yang rendah, dalam hal ini Telkomsel kurang gencar menginformasikan layanan NSP 1212 pada media cetak maupun elektronik, kejelasan informasi hanya dapat diperoleh apabila kita mendownloadnya melalui situs Telkomsel di internet. Secara keseluruhan respon konsumen memperoleh tanggapan yang cukup dari responden. Oleh karena itu Telkomsel harus merancang kegiatan pemasarannya yang sesuai dengan tahap kesiapan pembeli yaitu tahap pada area pengetahuan (cognitive response), area perasaan (affective response) dan area tindakan (behavioral response). Setelah pasar diketahui, perusahaan perlu menetapkan respon apa yang diinginkan, sehingga dapat menjalin hubungan dengan konsumennya agar mengadopsi produk baru yang ditawarkan

3. Berdasarkan hasil penelitian menyatakan bahwa consumer promotion memberikan pengaruh yang positif terhadap respon konsumen, maka penulis merekomendasikan agar Telkomsel harus tetap menjaga dan mempertahankan strategi consumer promotion nya yang sudah dijalankan dengan cara melakukan evaluasi kembali untuk setiap program-program promosi yang telah digunakan sehingga dapat diketahui seberapa efektif program tersebut dapat digunakan, selain itu untuk meningkatkan penjualan atau respon yang menurun setelah program promosi berakhir, perusahaan harus mulai merancang insentif baru yang akan ditawarkan kepada pelanggannya agar pelanggan kembali tertarik untuk menggunakan layanan NSP 1212.

\section{DAFTAR PUSTAKA}

Anderson, Vince. 2000. Strategic Marketing Management. New York: Houghton Miflin Company.

Asep Hermawan. 2006. Penelitian Bisnis Paradigma Kuantitatif. Jakarta: PT Gramedia Widia Sarana Indonesia.

Berkowitz. 2000. Marketing. Boston: Mc Graw Hill
Brannan, Tom. 2005. Integrated Marketing Communications. Diterjemahkan oleh Slamet.. Jakarta: PPM.

Buchari Alma. 2004. Kewirausahaan Edisi Revisi. Bandung: CV. Alfabeta.

Buchari Alma. 2004. Manajemen Pemasaran dan Pemasaran Jasa. Bandung: Alfabeta.

Cravens W. David. 1996. Pemasaran Strategis. Jilid 2. Jakarta: Erlangga.

Cravens, David W. Dan Piercy, Nigel F.. 2003 Strategic Marketing. Singapore: McGraw Hill, Inc.

David A. Aaker, V Kumar and George S. Day. 2004. Marketing Researcg Eight Adition. USA: John Willey and Sons Inc.

Engel, James F. 1994. Perilaku Konsumen. Jilid 1 dan 2. Jakarta: Binarupa Aksara.

Engel, James F. 1998. Perilaku Konsumen Edisi Keenam. Jakarta: Binarupa Aksara.

Fandy Tjiptono. 2002. Strategi Pemasaran Edisi II. Yogyakarta. Andi Offset

Fandy Tjiptono. 2007. Pemasaran Strategi. Yogyakarta. ANDI.

Frans M. Royan. 2004. Cluster Strategy. Jakarta: Gramedia Pustaka Utama.

Fredy Rangkuti. 2002. The Power of Brand. Jakarta. PT. Gramedia Pustaka Utama

Harun Al-Rasyid. 1994. Teknik Penarikan Sampel dan Penyusunan Skala. Bandung: UNPAD

Hermawan Kertajaya. 2004. On Brand. Bandung. PT Mizan Pustaka

Herper, W. Boyd. 2000. Manajemen Pemasaran: Suatu Pendekatan Strategis Orientasi Global. Jakarta: Erlangga.

Husein Umar. 2001. Metode Penelitian dan Aplikasi dalam Pemasaran. Jakarta. PT Gramedia Pustaka Umum

Indriantoro dan Supomo. 2002. Metodologi Penelitian Bisnis. Yogyakarta: BPFE.

Julian Cummins, Roddy Mullin. 2004. Sales Promotion. Jakarta: PT. Ikrar Mandiri Abadi.

Kotler, Philip and Gary Armstrong. 2005. Principles Of Marketing. PrenticeHall Inc.

Kotler, Philip, Keller dan Kevin Lane. 2006. Marketing Management. Pearson International Edition. New Jersey. Pearson Prentice Hall.

Kotler, Philip. 2005. Manajemen Pemasaran. Jakarta. Prenhallindo

Malhotra, Naresh K.. 2004. Basic Marketing Research, Application to Kontemporari Issue,. New Jersey: Pearson International Edition.

Mangkunegara, A.A Anwar Prabu. 2003. Perilaku Konsumen. Edisi Revisi. Bandung: Refika Aditama. 
Moh. Nasir. 2003. Metode Penelitian. Jakarta: Ghalia Indonesia.

Mowen C. John and Minor Michael. 2002. Perilaku Konsumen. Diterjemahkan oleh Lina Salim. Bandung: Erlangga.

Nugroho J. Setiadi. 2003. Perilaku Konsumen (Konsep dan Implikasi Untuk Strategi dan Penelitian Pemasaran. Yogyakarta. Andi

Nugroho J. Setiadi. 2003. Perilaku Konsumen dan Komunikasi Pemasaran. Bandung: Rosda karya.

Paul Peter and Jerry C. Olson. 2000. Consumer Behavior (Perilaku Konsumen dan Strategi Pemasaran). Jilid 1 dan 2. Diterjemahkan oleh Damos Sihombing. Jakarta: Erlangga.

Ratih Hurriyati. 2005. Manajemen Pemasaran Jasa dan Loyalitas. Bandung: CV. Alfabeta.

Schiffman, Leon.G dan Kanuk, Leslie. 200). Consumer Behaviour. Jakarta: Prentice Hal Internasional.

Shimp, A. Terence. 2003. Periklanan Promosi Aspek Tambahan Komunikasi Pemasaran Terpadu. Diterjemahkan oleh Revyani Sjahrial dan Dyah Anikasari. Jakarta; Erlangga

Singarimbun, Masri dan Sofian Effendi. 1995. Metode Penelitian Survei. Jakarta: LP3ES.

Stanton, Wiliam J.. 1996. Prinsip Pemasaran Edisi VII. Jakarta: Erlangga.

Sudjana. 2005. Metoda Statistika. Bandung: Tarsito.

Sugiyono. 2002. Metode Penelitian Bisnis, Bandung: CV. Alfabeta.

Sugiyono. 2005. Statistika untuk Penelitian. Bandung: CV. Alfabeta.

Sugiyono. 2006. Metode Penelitian Bisnis Bandung: CV. Alfabeta.

Suharsimi Arikunto 2006. Prosedur Penelitian Suatu Pendekatan Praktek. Jakarta: Rineka Cipta.

Sutisna. 2004. Perilaku Konsumen dan Komunikasi Pemasaran. Bandung: Rosda Karya

Swastha Dh, Basu, dan Hani Handoko. 1997. Manajemen Pemasaran Analisis Perilaku Konsumen. Edisi Tiga. Yogyakarta: Liberty.

\section{Website}

www.bkkbn.go.id; www.google.com; www.swa.com www.telkomsel.co.id; www.telkomsel.com; www.telkom.com; www.wordpress.com 